\title{
A molecular phylogeny of Graphidaceae (Ascomycota, Lecanoromycetes, Ostropales) including 428 species
}

\author{
Eimy Rivas Plata ${ }^{1,2}$, Sittiporn Parnmen', Bettina Staiger ${ }^{3}$, Armin Mangold ${ }^{4}$, \\ Andreas Frisch ${ }^{5}$, Gothamie Weerakoon ${ }^{6}$, Jesús E. Hernández M.7, \\ Marcela E. S. Cáceres ${ }^{8}$, Klaus Kalb ${ }^{3,9}$, Harrie J. M. Sipman ${ }^{10}$, \\ Ralph S. Common"', Matthew P. Nelsen ${ }^{1,12}$, \\ Robert Lücking', H. Thorsten Lumbsch'
}

I Department of Botany, The Field Museum, 1400 South Lake Shore Drive, Chicago, Illinois 60605-2496, U.S.A. 2 Department of Biology, Duke University, 125 Science Drive, Durham, North Carolina 27708, U.S.A. 3 University of Regensburg, Institute for Botany, Universitätsstr. 31, D-93040 Regensburg, Germany 4 Universität Duisburg-Essen, Botanisches Institut, Universitätsstr. 5, D-45141 Essen, Germany 5 National Museum of Nature and Science, 4-1-1 Amakubo, Tsukuba, Ibaraki, 305-0005 Japan 6 Department of Botany, University of Sri Jayawardenepura, Sri Lanka 7 Fundación Instituto Botánico de Venezuela, Ave. Salvador Allende, Jardín Botánico de Caracas, Universidad Central de Venezuela, Apartado \# 2156, Caracas 1010-A, Venezuela 8 Departamento de Biociências, Universidade Federal de Sergipe, CEP: 49.500-000, Itabaiana, Sergipe, Brasil 9 Lichenologisches Institut Neumarkt, Im Tal 12, D-92318 Neumarkt, Germany 10 Botanischer Garten and Botanisches Museum Berlin Dahlem, Königin-Luise-Strasse 6-8, D-14195 Berlin, Germany I I 534 Fenton St., Lansing, Michigan 48910, U.S.A. 12 Committee on Evolutionary Biology, University of Chicago, 1025 E. 57th Street, Chicago, Illinois 60637, U.S.A

Corresponding author: Robert Lücking (rlucking@fieldmuseum.org)

Academic editor: T. Lumbsch | Received 7 June 2012 | Accepted 15 November 2012 | Published 23 April 2013

Citation: Rivas Plata E, Parnmen S, Staiger B, Mangold A, Frisch A, Weerakoon G, Hernández M JE, Cáceres MES, Kalb K, Sipman HJM, Common RS, Nelsen MP, Lücking R, Lumbsch HT (2013) A molecular phylogeny of Graphidaceae (Ascomycota, Lecanoromycetes, Ostropales) including 428 species. In: Boonpragob K, Crittenden P, Lumbsch HT (Eds) Lichens: from genome to ecosystems in a changing world. MycoKeys 6: 55-94. doi: 10.3897/mycokeys.6.3482

\begin{abstract}
We present a comprehensive molecular phylogeny of the lichen family Graphidaceae (subfamilies Graphidoideae and Fissurinoideae) based on partial sequences of the mtSSU, nuLSU rDNA, and RPB2 loci. The phylogeny includes all currently available sequences in Genbank plus 897 newly generated sequences, from a total of 908 ingroup OTUs representing 428 species. The phylogeny supports the synomymy of Graphidaceae and Thelotremataceae and confirms that rounded and lirellate ascomata evolved multiple times in unrelated clades within the family. The phylogenetic distinctiveness of Fissurinoideae versus
\end{abstract}

Copyright Eimy Rivas Plata et al. This is an open access article distributed under the terms of the Creative Commons Attribution License 3.0 (CC-BY), which permits unrestricted use, distribution, and reproduction in any medium, provided the original author and source are credited. 
Graphidoideae is also supported in our extended taxon sampling. The three-gene phylogeny suggest that in addition to the three tribes previously established for the major clades within subfamily Graphidoideae, several further clades exist that might represent additional tribes. Specifically, the Leptotrema clade is excluded from tribe Ocellularieae and the Carbacanthographis, Heiomasia, Topeliopsis, and Wirthiotrema clades are excluded from tribe Thelotremateae. The phylogenetic position of these clades remains unresolved but they are not supported as belonging to these larger tribes. Based on the results, the current status and problems are discussed for all clades and genera currently accepted within the family.

\section{Key words}

Asterothryiaceae, Fissurinoideae, Gomphillaceae, Graphideae

\section{Introduction}

Graphidaceae, which is currently accepted to include the previously independent families Thelotremataceae (Mangold et al. 2008a, Rivas Plata et al. 2012a), Gomphillaceae, Asterothyriaceae, and Solorinellaceae (Baloch et al. 2010, Rivas Plata et al. 2012a, b), is the second largest family of lichenized fungi and the dominant element of lichen communities in tropical regions, with over 1800 accepted species (Staiger 2002, Frisch et al. 2006a, Archer 2006, 2007, 2009, Lücking and Rivas Plata 2008, Lücking 2009, Lücking et al. 2008, 2009, Rivas Plata et al. 2008, 2012a, Mangold et al. 2009). Quantitative extrapolations and molecular data available for species complexes, as well as continuous new discoveries, suggest that the family may actually contain well over 2000 species (Lücking 2012, Rivas Plata and Lücking 2012, Rivas Plata et al. 2012b, Sipman et al. 2012).

For over 100 years, family and genus concepts in this group were based on apothecia and ascospore types, separating most of the species into groups with either rounded, lirellate, or pseudostromatic ascomata and, for each ascoma type, into four genera depending on whether ascospores were transversely septate or muriform and hyaline or pigmented (Müller 1887, Hale 1974, 1978, Wirth and Hale 1963, 1978, Staiger 2002, Frisch et al. 2006a): rounded (Thelotremataceae): Ocellularia, Thelotrema, Phaeotrema, Leptotrema; Graphidaceae: lirellate (Graphidaceae): Graphis, Graphina, Phaeographis, Phaeographina; pseudostromatic (Graphidaceae): Glyphis, Medusulina, Sarcographa, Sarcographina). This concept was highly schematic and challenged by several authors, e.g. in the former Thelotremataceae by Salisbury $(1971,1972,1978)$ and Hale $(1980,1981)$. The latter author proposed an alternative generic concept with three genera based on excipular structures: carbonized and lacking periphysoids (Ocellularia), non-carbonized and lacking periphysoids (Myriotrema), and non-carbonized and with periphysoids (Thelotrema). However, delimitation of very large genera with well over 300 species each and the problems with generic assignment of aberrant taxa made this concept unsatisfactory. In addition, subsequent phylogenetic studies showed that these genera were not monophyletic (Frisch et al. 2006a, Mangold et al. 2008a). Also, no comparable solution was proposed for lirellate and stromatic species classified 
in Graphidaceae, which until recently remained essentially unchanged from ascosporebased concepts established in the 19th century (Wirth and Hale 1963, 1978, Archer 1999, 2000, 2001a-d, 2002, Staiger 2002).

Major systematic revisions of both families only started after turn of the millenium, with two monographic treatments put forward by Staiger (2002) and Frisch et al. (2006a). In these, a more detailed approach to genus classification was employed, based on a combination of characters such as thallus structure, excipular structure, hamathecium type, ascospore type, and secondary chemistry. This refined classification, which resulted in many new genera (Staiger 2002; Frisch et al. 2006a, Kalb 2009, Rivas Plata et al. 2010a, Lücking et al. 2011, Cáceres et al. 2012, Sipman et al. 2012) has subsequently been tested using molecular approaches, with a growing amount of sequence data available (Staiger 2002, Kalb et al. 2004, Lumbsch et al. 2008, Frisch et al. 2006b, Staiger et al. 2006, Mangold et al. 2008a, Baloch et al. 2010, Rivas Plata and Lumbsch 2011, Rivas Plata et al. 2012a, b). Using molecular data, it was also shown that Graphidaceae and Thelotremataceae were non-monophyletic and consequently Thelotremataceae was included in Graphidaceae. Within Graphidaceae five major clades were distinguished based on supported monophyletic clades (Mangold et al. 2008a, Rivas Plata and Lumbsch 2011, Rivas Plata et al. 2012a). In addition, two separate studies supported three further families, Gomphillaceae, Asterothyriaceae, and Solorinellaceae, as part of Graphidaceae (Baloch et al. 2010, Rivas Plata et al. $2012 \mathrm{a}, \mathrm{b}$ ). The inclusion of the latter has been controversely discussed (Aptroot 2012, Rivas Plata et al. 2012a), since it appears to disrupt the more or less morphologically homogeneous entity formed by subfamilies Fissurinoideae and Graphidoideae; on the other hand, as pointed out by Sipman et al. (2012), the differences between Gomphilloideae and the remaining Graphidaceae are merely gradual in nature. It can be argued that Graphidaceae could be retained as a paraphyletic entity excluding Gomphillaceae (Aptroot 2012). However, the known topology does not support this view since Gomphilloideae is strongly supported as sister to Fissurinoideae on a long branch, i.e. Fissurinoideae is more closely related to Gomphilloideae than to Graphidoideae and hence, Graphidaceae after exclusion of Gomphillaceae would be polyphyletic rather than paraphyletic. In the present study, subfamily Gomphilloideae is not treated since only few species have been sequenced and this clade will be dealt with in a separate contribution.

In this paper, we present the most recent molecular phylogeny of Graphidaceae, focusing on subfamilies Fissurinoideae and Graphidaceae, using a supermatrix approach of all available and newly generated sequences of the mtSSU, nuLSU rDNA, and $R P B 2$ gene partitions. Based on the results, we discuss the progress and problems in the delimitation of infra-family and genus-level taxa in the family. We did not include subfamily Gomphilloideae in this analysis since this subfamily will be treated in detail in a separate paper and its inclusion or exclusion does not affect the topology of subfamilies Fissurinoideae and Graphidoideae. 


\section{Material and methods}

Partial sequences of the mtSSU rDNA, nuLSU rDNA and the RPB2 gene were obtained from 907 ingroup OTUs representing 428 species in Graphidaceae (subfamilies Fissurinoideae and Graphidoideae). Thirteen additional species from the ostropalean families Stictidaceae, Porinaceae, Gyalectaceae, and Coenogoniaceae, were used as outgroup. A total of 865 new ingroup sequences were newly generated (Appendix 1): 481 for the $\mathrm{mtSSU}, 260$ for the nuLSU, and 124 for the RPB2 gene. In addition, 433 ingroup sequences were downloaded from GenBank (Appendix 1): 263 for the mtSSU, 151 for the nuLSU, and 19 for the RPB2 gene. Unfortunately, for many OTUs, sequence representation was incomplete, either because original DNA extracts from GB sequences were unavailable or because PCR did not work, especially with nuLSU and $R P B 2$ primers. Thus, of a potential total of $907 \times 3=2721$ ingroup sequences, 1298 $(48 \%)$ were assembled in the dataset. The mtSSU was most complete (744 out of 907 or $82 \%$ ), followed by the nuLSU (411 out of 907 or $45 \%$ ) and RPB2 (143 out of 907 or $16 \%$ ). A total of 35 further sequences, particularly of the nuLSU, could not be used because of contaminants or else unexplained conflict.

New sequences were generated for this study using the Sigma REDExtractN-Amp Plant PCR Kit (St. Louis, Missouri, SA) for DNA isolation following the manufacturer's instructions, except that $40 \mu \mathrm{L}$ of extraction buffer and $40 \mu \mathrm{L}$ dilution buffer were used. DNA dilutions $(5 \mathrm{x})$ were used in PCR reactions of the genes coding for the nuLSU, mtSSU and RPB2, respectively. Primers for amplification were: (a) for nuLSU: AL2R (Mangold et al. 2008a), and nu-LSU-1125-3' (= LR6) (Vilgalys and Hester 1990), (b) for mtSSU: mr-SSU1 and Mr-SSU3R (Zoller et al. 1999), and (c) for RPB2: fRPB2-7cF and fRPB2-11aR (Liu et al. 1999). PCR reactions contained 5.0 $\mu \mathrm{L}$ R4775 Sigma REDExtract-N-Amp "' PCR ReadyMix, $0.5 \mu \mathrm{L}$ of each primer $(10 \mu \mathrm{M}), 2 \mu \mathrm{L}$ genomic DNA extract and $2 \mu \mathrm{L}$ distilled water for a total of $10 \mu \mathrm{L}$. Thermal cycling parameters were: (1) for nuLSU: initial denaturation for $5 \mathrm{~min}$ at $94^{\circ} \mathrm{C}$, followed by 35 cycles of $30 \mathrm{~s}$ at $95^{\circ} \mathrm{C}, 30 \mathrm{~s}$ at $58^{\circ} \mathrm{C}, 1 \mathrm{~min}$ at $72^{\circ} \mathrm{C}$, and a final elongation for $10 \mathrm{~min}$ at $72^{\circ} \mathrm{C}$; (2) for $\mathrm{mtSSU}$ : initial denaturation for $5 \mathrm{~min}$ at $95^{\circ} \mathrm{C}$, followed by 35 cycles of $45 \mathrm{~s}$ at $94^{\circ} \mathrm{C}, 1 \mathrm{~min}$ at $50^{\circ} \mathrm{C}, 1 \mathrm{~min} 30 \mathrm{~s}$ at $72^{\circ} \mathrm{C}$, and a final elongation for $10 \mathrm{~min}$ at $72^{\circ} \mathrm{C}$; and (3) for $R P B 2$ : initial denaturation for $3 \mathrm{~min}$ at $95^{\circ} \mathrm{C}$, then $1 \mathrm{~min}$ at $95^{\circ} \mathrm{C}$, and 37 cycles of $1 \mathrm{~min}$ at $57^{\circ} \mathrm{C}, 1$ min at $58^{\circ} \mathrm{C}, 1 \mathrm{~min}$ at $59^{\circ} \mathrm{C}, 1 \mathrm{~min}$ at $60^{\circ} \mathrm{C}, 1 \mathrm{~min}$ at $61^{\circ} \mathrm{C}, 1 \mathrm{~min}$ at $62^{\circ} \mathrm{C}, 1 \mathrm{~min}$ at $63^{\circ} \mathrm{C}, 1 \mathrm{~min}$ at $64^{\circ} \mathrm{C}$ and $1.5 \mathrm{~min}$ at $72^{\circ} \mathrm{C}$, and a final elongation for $10 \mathrm{~min}$ at $72^{\circ} \mathrm{C}$. Samples were visualized on a $1 \%$ ethidium bromide-stained agarose gel under UV light and bands were gel extracted, heated at $70^{\circ} \mathrm{C}$ for 5 minutes, cooled to $45^{\circ}$ $\mathrm{C}$ for 10 minutes, treated with $1 \mu \mathrm{L}$ GELase (Epicentre Biotechnologies, Madison, WI, USA) and incubated at $45^{\circ} \mathrm{C}$ for at least 24 hours. The $10 \mu \mathrm{l}$ cycle sequencing reactions consisted of 1-1.5 $\mu \mathrm{l}$ of Big Dye version 3.1 (Applied Biosystems, Foster City, California, U.S.A.), 2.5-3 $\mu \mathrm{l}$ of Big Dye buffer, $6 \mu \mathrm{M}$ primer, 0.75-2 $\mu \mathrm{l}$ gelased PCR product and water. Samples were sequenced with PCR primers. The cycle sequencing conditions were as follows: $96^{\circ} \mathrm{C}$ for 1 minute, followed by 25 cycles of 
$96^{\circ} \mathrm{C}$ for 10 seconds, $50^{\circ} \mathrm{C}$ for 5 seconds and $60^{\circ} \mathrm{C}$ for 4 minutes. Samples were precipitated and sequenced using Applied Biosystems 3730 DNA Analyzer (Foster City, California, U.S.A.), sequences were assembled in SeqMan 4.03 (DNASTAR) and submitted to GenBank (Appendix 1).

Sequences were arranged into multiple sequence alignments (MSA) for each gene using BIOEDIT 7.09 (Hall 1999) and automatically aligned with MAFFT using the --auto option (Katoh and Toh 2005). The unaligned MSA for the mtSSU and nuLSU gene partitions were also submitted to the GUIDANCE web server at http://guidance.tau.ac.il to assess alignment confidence scores for each site (Penn et al. 2010a, b). GUIDANCE uses a MAFFT alignment and returns a colored MSA that allows delimiting ambiguously aligned portions of the MSA. These were then excluded from further analysis. Introns were deleted from the nuLSU gene partition because of their random occurrence but kept in the mtSSU partition if consistent within species or species groups. This resulted in alignments of 995 sites for the mtSSU, 972 sites for the nuLSU, and 951 for RPB2, for a total of 2918 sites in the combined dataset. After testing for supported topological conflicts (Mason-Gamer and Kellogg 1996, Miadlikowska and Lutzoni 2000, Kauff and Lutzoni 2002), the three genes were combined into a single supermatrix. Individual datasets and the combined supermatrix were subjected to maximum likelihood search using the RAxML-HPC BlackBox 7.3.2 on the Cipres Gateway server (Stamatakis 2006, Stamatakis et al. 2005, 2008; Miller et al. 2010; http:/www.phylo.org/portal2/login!input.action), with parametric bootstrapping generating 350 replicates as automatically determined by RAxML using a saturation criterion. The universal GTR-Gamma model was chosen for the analysis.

\section{Results}

In our analysis, the core Graphidaceae is divided into two strongly supported clades representing subfamilies Fissurinoideae and Graphidoideae (Fig. 1, see Appendix 2 for entire, fully resolved tree). Subfamily Graphidoideae is further divided into six larger and smaller clades, some of which form unsupported clusters. These clades largely represent species with either lirellate or rounded ascomata, but no supported division into two clades representing either ascomata type is evident; also, subfamily Fissurinoideae includes both species with lirellate and rounded ascomata.

Within subfamily Fissurinoideae, species of Fissurina s.lat. form several clades, indicating that the genus as currently defined is polyphyletic (Fig. 2). Most of the clades correspond to particular morphotypes: the $F$. humilis, F. nitidescens, and $F$. nigrolabiata clades (Fissurina 2-4) represent species with carbonized lirellae, the $F$. pseudostromatica clade (Fissurina 6) species with pseudostromatic lirellae, the $F$. astroisidiata clade (Fissurina 7 ) a species with platythecioid lirellae, and the F. dumastii clade (Fissurina s.str.) species with uncarbonized lirellae. Nested within the backbone are the clades corresponding to the genera Clandestinotrema, Cruentotrema, Dyplolabia, Enigmotrema, and Pycnotrema. Clandestinotrema forms two sister clades, one 


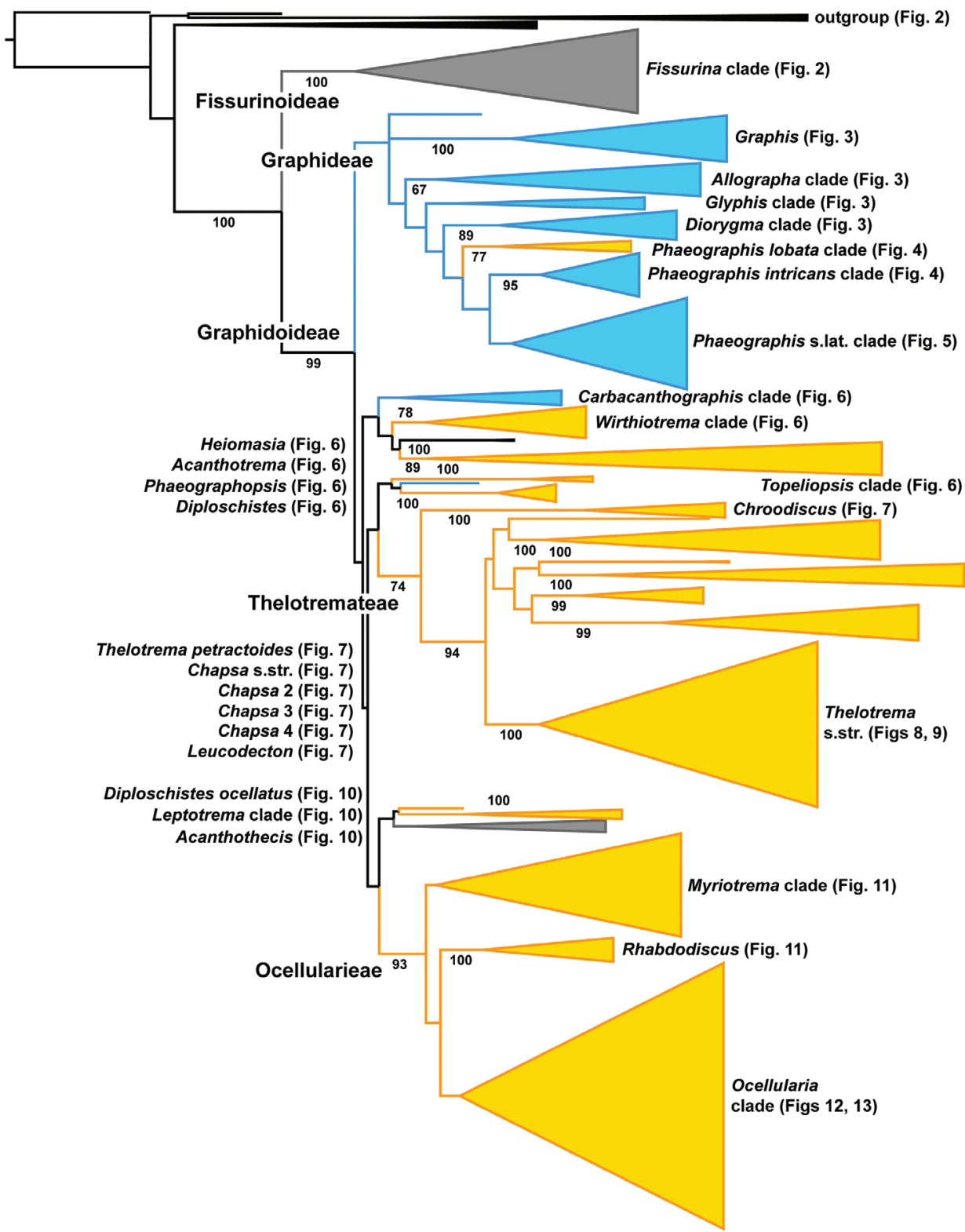

Figure I. Cartoon tree showing the major clades distinguished within Graphidaceae with bootstrap support given next to branches. Blue clades indicate graphidoid taxa (lirellate or pseudostromatic ascomata), orange clades indicate thelotremoid taxa (rounded ascomata), and grey clades indicate mixed graphidoid and thelotremoid taxa. Bootstrap support is indicated for major clades and figures with detailed clade information are indicated for each clade. The entire, detailed tree is available as Appendix 2.

corresponding to species with narrow apothecial pores with entire margin and fingerlike columella, represented by the type species, C. clandestinum, and the other to species with broadly open apothecia with fissured margin and broad-stump-shaped 


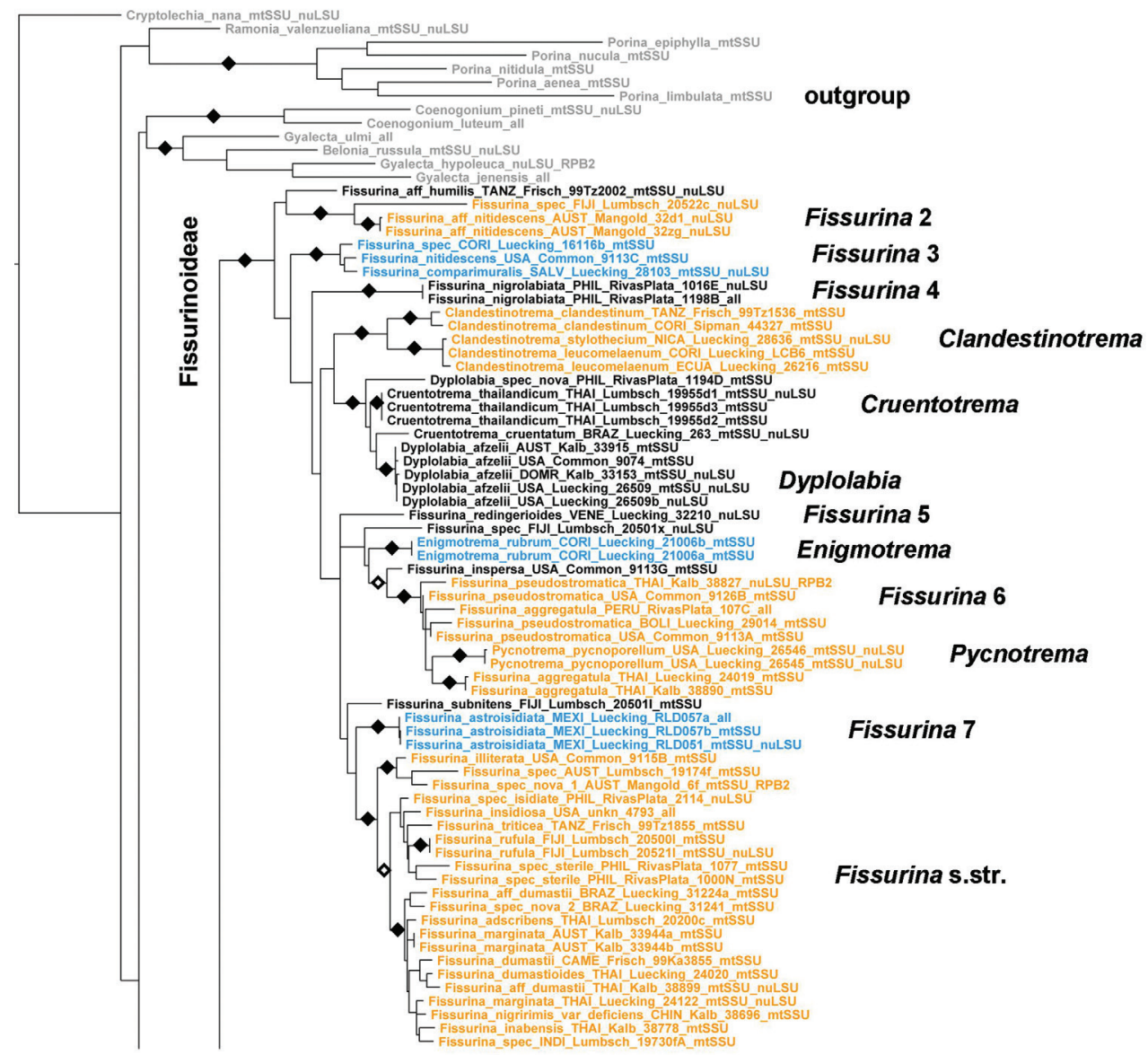

Fig. 3

Figure 2. Detailed topology of the Fissurina clade (subfamily Fissurinoideae). Genus level clades are highlighted. Bootstrap support is indicated as black (90\% and higher) and black-and-white $(70 \%$ and higher) symbols. For specimen information and GenBank numbers see Appendix 1. The entire, fully resolved tree with detailed bootstrap support values is available as Appendix 2.

columella, represented by C. leucomelaenum and C. stylothecium. Cruentotrema is nested within Dyplolabia, and each genus forms two separate clades each, which contradicts their pronounced morphological differences. Enigmotrema and Pycnotrema are nested within Fissurina s. lat.

The first clade in subfamily Graphidoideae represents the large tribe Graphideae (unsupported here but supported in previous studies), which can be divided into several larger and smaller clades (Figs 3-5). Graphis s.str., the type genus of the family, is the most unique clade phylogenetically (Fig. 3); it includes part of Hemithecium which corresponds to Graphis except in the uncarbonized lirellae. Platythecium is polyphyletic, forming two separate clades representing the P. allosporellum (P. sphaerosporellum) and $P$. grammitis groups. Both differ morphologically and chemically in that 
Fig. 2

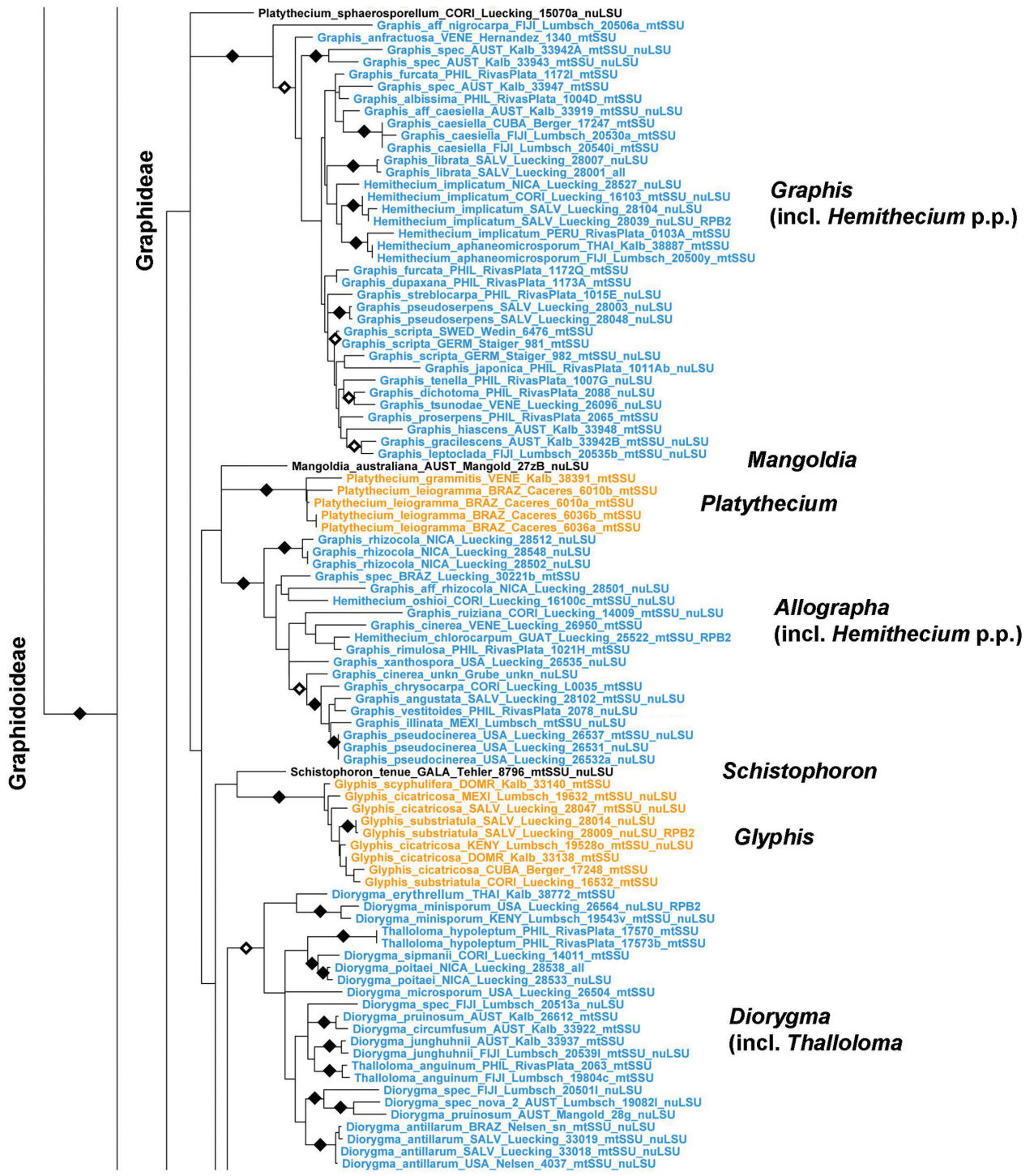

Fig. 5 Fig. 6 Fig. 4

Figure 3. Detailed topology of the Graphis, Platythecium, Allographa, Glyphis, and Diorygma clades (subfamily Graphidoideae tribe Graphideae p.p.). Genus level clades are highlighted. Bootstrap support is indicated as black ( $90 \%$ and higher) and black-and-white (70\% and higher) symbols. For specimen information and GenBank numbers see Appendix 1. The entire, fully resolved tree with detailed bootstrap support values is available as Appendix 2.

the first group includes species with basally carbonized excipulum and the testacein chemosyndrome. The genus Allographa includes species of the G. cinerea group and part of Hemithecium with large ascospores. A new small genus, Mangoldia (described in a separate paper; Lücking et al. 2012), which is characterized by Phaeographis le- 
Fig. 3

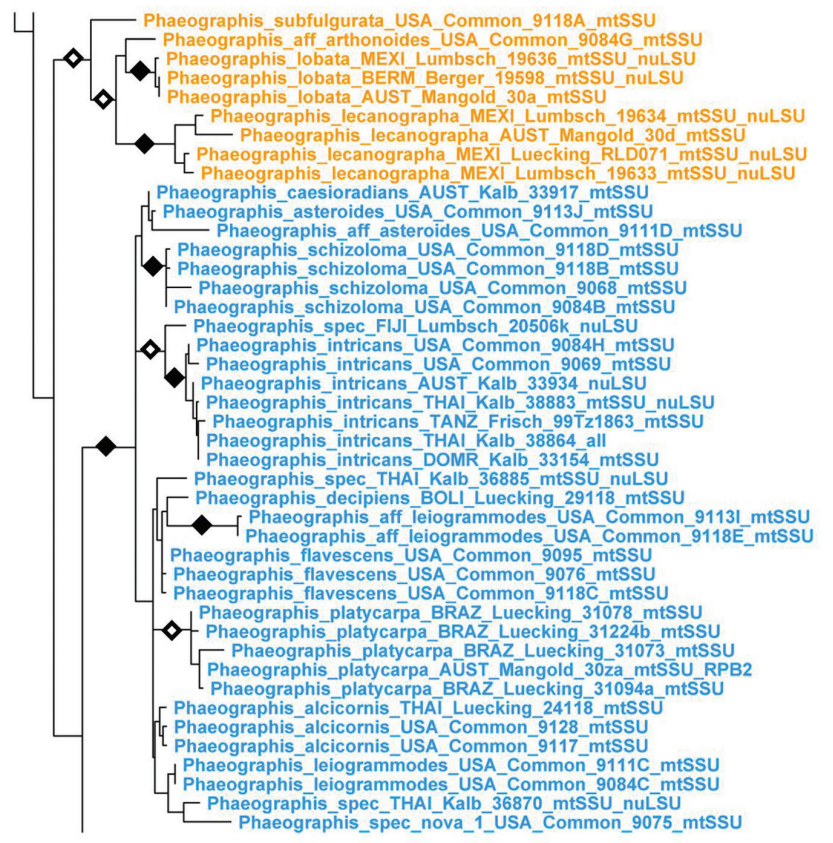

\section{Phaeographis lobata group}

\section{Phaeographis intricans group (Creographa)}

Fig. 5

Figure 4. Detailed topology of the Phaeographis s.lat. clade p.p. (subfamily Graphidoideae tribe Graphideae p.p.). Genus level clades are highlighted. Bootstrap support is indicated as black ( $90 \%$ and higher) and black-and-white (70\% and higher) symbols. For specimen information and GenBank numbers see Appendix 1 . The entire, fully resolved tree with detailed bootstrap support values is available as Appendix 2.

canographa-like ascomata but Graphis-type ascospores, forms a separate clade with unresolved position. Glyphis is strongly supported as monophyletic and the mazaediate Schistophoron persistently clusters at the base of Glyphis but without support. Dioryg$m a$ includes the genus Thalloloma and also a species formerly placed in the arthonioid genus Herpothallon but now recombined as Diorygma antillarum (Nelsen et al. 2012).

Phaeographis and allied genera (Creographa, Halegrapha, Leiorreuma, Malmographina, Pallidogramme, Phlegographa, Platygramme, Sarcographa, Thecaria) form a complex clade in which generic relationships appear diffuse, with many genera as currently defined being non-monophyletic (Figs 4-5). The Phaeographis lobata group, including $P$. lecanographa and allies, forms an unsupported sister-group relationship to the remaining species (Fig. 4). The clade itself is supported by both molecular data and morphological characters and deserves generic status. Species of the Phaeographis intricans group from a strongly supported clade sister to all remaining species, for which the name Creographa is available; however, one species with identical morphology, anatomy, and chemistry, $P$. aff. intricans (Phaeographis 4), clusters outside this clade, suggesting a remarkable case of parallel evolution. Platygramme s.str. appears to be monophyletic but some species currently classified in that genus, with a different 
Fig. 4

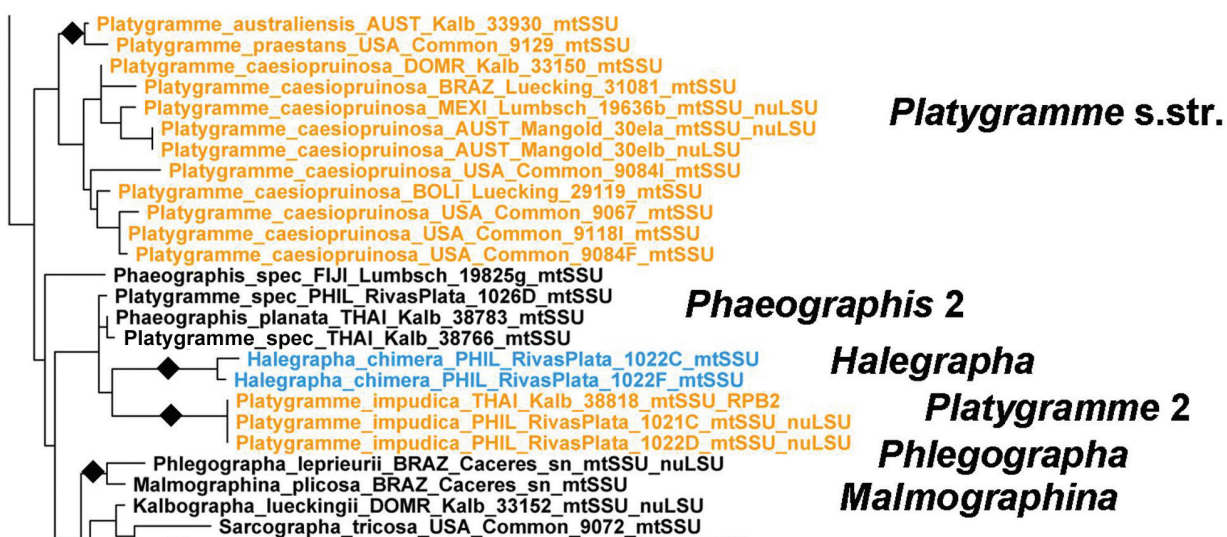

\title{
Phaeographis 3
}

\author{
Pallidogramme
}

Thecaria s.str.

\section{Phaeographis 4}

\section{Sarcographa (incl. Leiorreuma and Thecaria p.p.)}

Figure 5. Detailed topology of the Phaeographis s.lat. clade p.p. (subfamily Graphidoideae tribe Graphideae p.p.). Genus level clades are highlighted. Bootstrap support is indicated as black ( $90 \%$ and higher) and black-and-white (70\% and higher) symbols. For specimen information and GenBank numbers see Appendix 1 . The entire, fully resolved tree with detailed bootstrap support values is available as Appendix 2.

lirellae morphology (thick labia and concealed disc), such as P. impucida (Platygramme 2) cluster outside (Fig. 5). Halegrapha is supported as monophyletic, with an unsupported sister-group relationship to Platygramme impudica (Platygramme 2). Both share Graphis-like lirellae but differ in thallus morphology. Two morphologically unique 
species classified in separate genera, Malmographina plicosa and Phlegographa leprieurii, form a supported sister group, unsupported sister to the remaining species of Phaeographis s.lat. Malmographina resembles Allographa in lirellae morphology, whereas Phlegographa is externally similar to Glyphis. The remaining species form several separate clades representing Phaeographis s.str., Phaeographis s.lat. (Phaeographis 2-4), Pallidogramme, Sarcographa, and Thecaria. The latter is polyphyletic, with T. montagnei nested within Sarcographa; also nested within that genus is Leiorreuma hypomelaenum, whereas Sarcographina glyphiza falls outside.

The next clades in subfamily Graphidoideae (Fig. 6) are small clades that were previously assigned to tribe Thelotremateae (Rivas Plata et al. 2012a) but in this study are not supported to form part of that tribe; their phylogenetic position remains unresolved. The Carbacanthographis clade includes two groups with lirellate ascomata that have apically spinulose periphysoids (Carbacanthographis) or paraphyses (Acanthothecis 2); the two lineages are otherwise separated by carbonized (Carbacanthographis) versus uncarbonized (Acanthothecis 2) lirellae, and the latter also differ in their corticate thallus and striate lirellae. This clade is phylogenetically and morphologically quite distinct from Acanthothecis s.str. (see below; Fig. 9) and deserves generic status. The Wirthiotrema clade includes genera and species previously mostly classified as Thelotrema, but apparently not related to Thelotrema s.str. The dominant secondary chemistry of this clade is stictic acid, present in nearly all species. Wirthiotrema itself is monophyletic and characterized by a dense, splitting cortex and non-amyloid ascospores with thickened septa. A second subclade is formed by Thelotrema bicinctulum, which resembles a Myriotrema with double margin but differs in its chemistry and rudimentary periphysoids. A third subclade is formed by Chapsa platycarpa and Thelotrema leucophthalmum, two species that, although previously assigned to different genera, are remarkably similar morphologically. The name Asteristion is available for this clade. Finally, the Nadvornikia subclade includes the mazaediate genus Nadvornikia as well as two non-mazaediate, lepadinoid species, Leucodecton expallescens and Myriotrema peninsulae. The latter is remarkably similar to Nadvornikia superficially except for the persistent, non-mazaediate hymenium. The next clade comprises the enigmatic, sterile genus Heiomasia. The next clade is formed by Topeliopsis and allied genera (Melanotopelia and Schizotrema), the genus Schizotrema apparently not being monophyletic, with one undescribed species forming a sister group relationship with Topeliopsis and another with Melanotopelia. Chapsa lamellifera is supported as nested within Topeliopsis but on a very long branch; morphologically it fits into that genus but differs by its very large apothecia. Finally, the last, unsupported clade comprises three subclades corresponding to three genera with unique morpho-ecological features: the chroodiscoid Acanthotrema, the mazaediate-lirellate Phaeographopsis, and the chroodiscoid-lecanoroid Diploschistes, which features a chlorococcoid photobiont and usually grows on soil or rock. These genera are morphologically and ecologically very disparate and their clustering might not reflect their true phylogenetic relationships, particularly since a long branch leads to each genus. Diploschistes appears non-monophyletic since D. ocellatus clusters outside the clade (see below; Fig. 10). 
Fig. 3

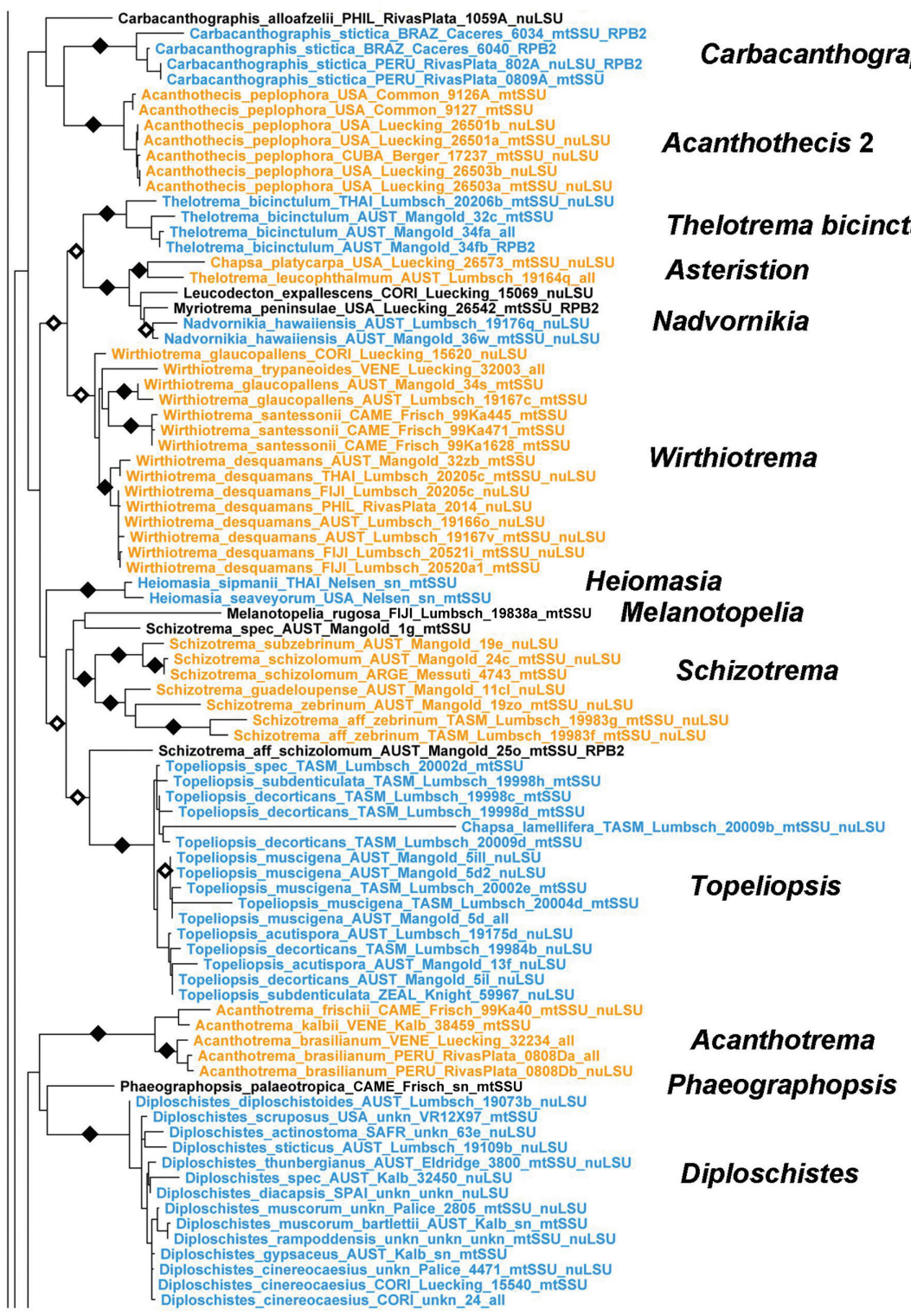

Fig. 7

Figure 6. Detailed topology of the Acanthothecis s. lat., Acanthotrema, Carbacanthographis, Diploschistes, Heiomasia, Nadvornikia, Phaeographopsis, Schizotrema, Topeliopsis, and Wirthiotrema clades (subfamily Graphidoideae). Genus level clades are highlighted. Bootstrap support is indicated as black ( $90 \%$ and higher) and black-and-white (70\% and higher) symbols. For specimen information and GenBank numbers see Appendix 1. The entire, fully resolved tree with detailed bootstrap support values is available as Appendix 2. 
Fig. 6

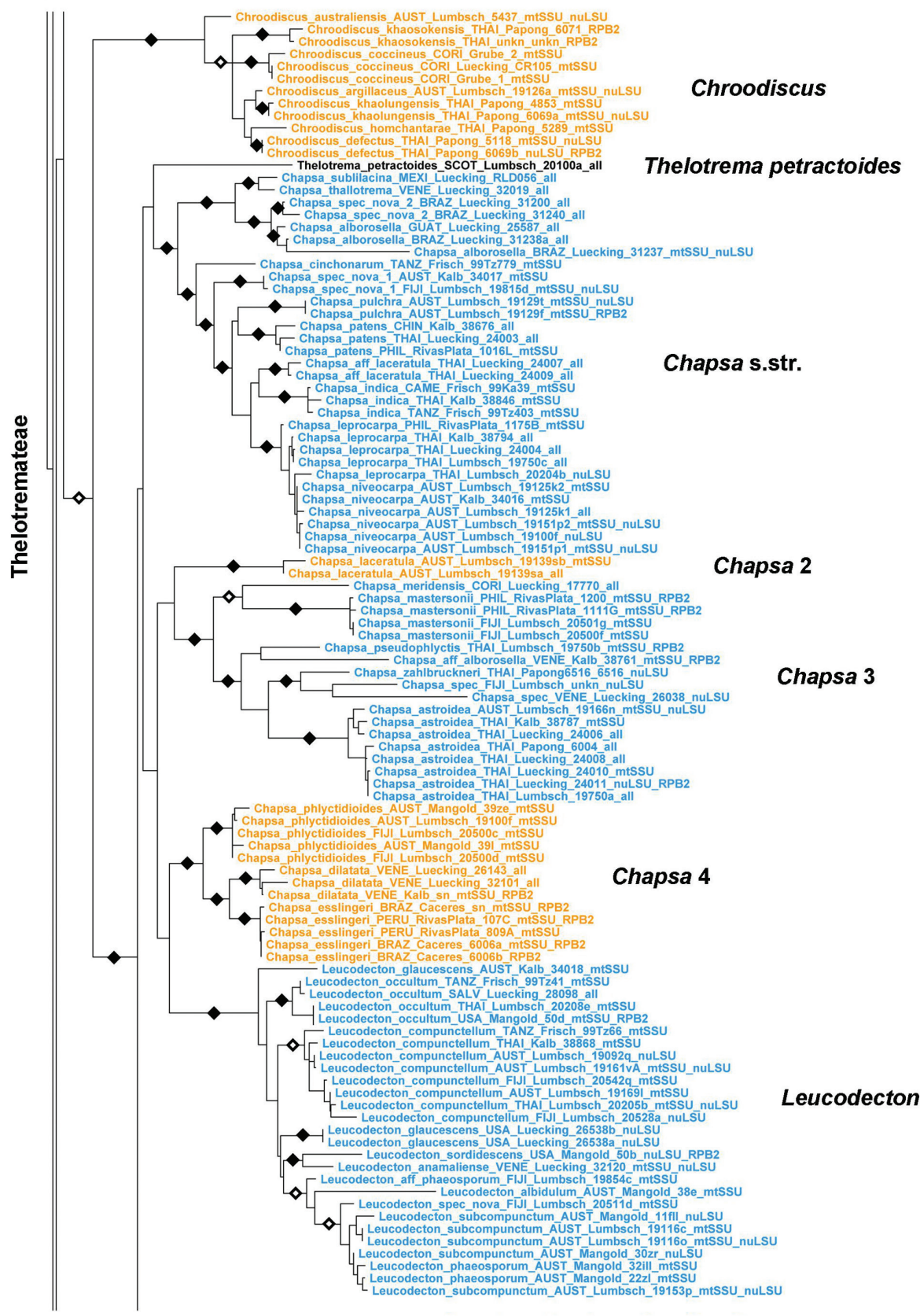

Fig. 10 Fig. 8

Figure 7. Detailed topology of the Chroodiscus, Chapsa s.lat., and Leucodecton clades (subfamily Graphidoideae tribe Thelotremateae p.p.). Genus level clades are highlighted. Bootstrap support is indicated as black (90\% and higher) and black-and-white (70\% and higher) symbols. For specimen information and GenBank numbers see Appendix 1. The entire, fully resolved tree with detailed bootstrap support values is available as Appendix 2. 
Fig. 7

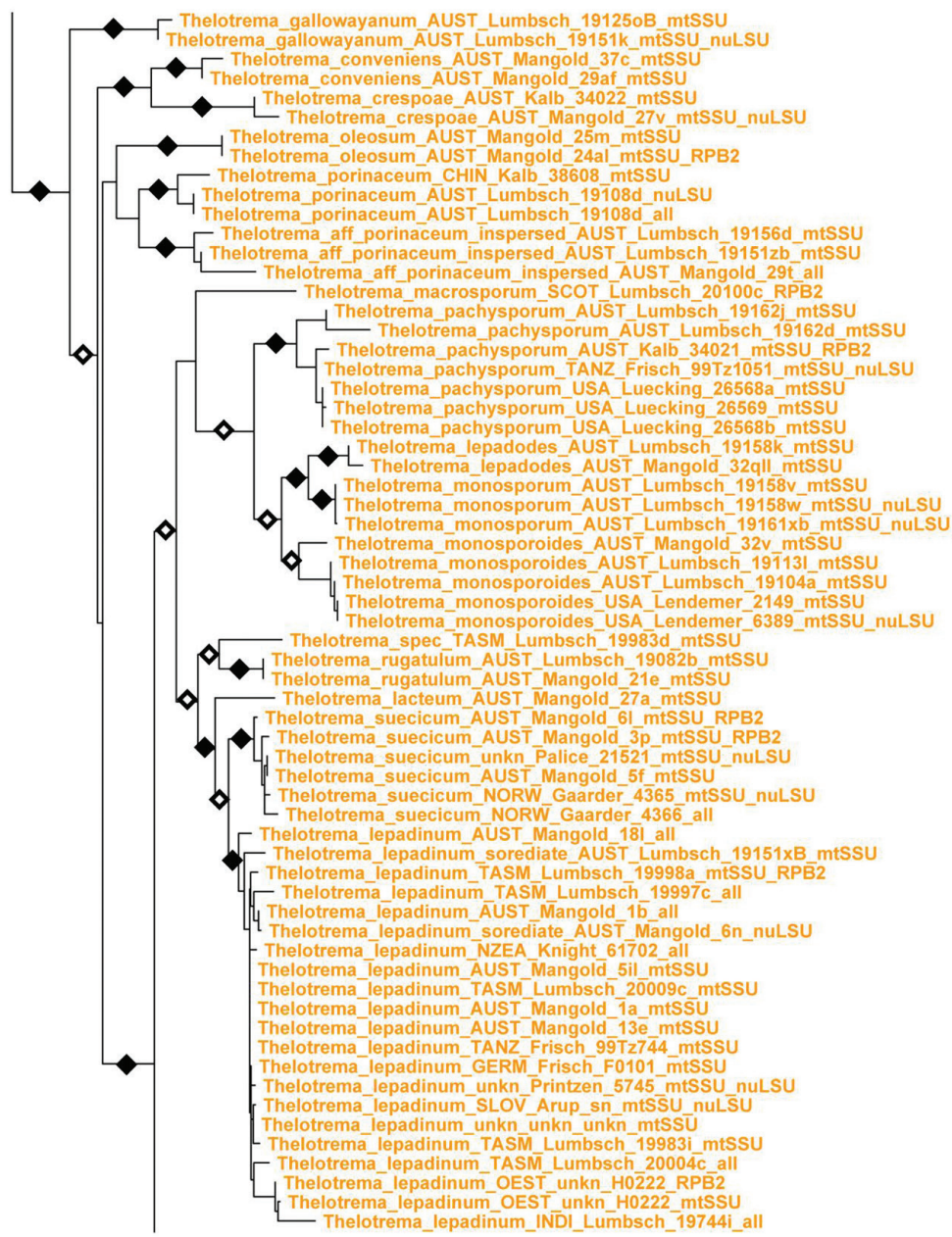

Thelotrema

Fig. 9

Figure 8. Detailed topology of the Thelotrema clade p.p. (subfamily Graphidoideae tribe Thelotremateae p.p.). Genus level clades are highlighted. Bootstrap support is indicated as black ( $90 \%$ and higher) and black-and-white (70\% and higher) symbols. For specimen information and GenBank numbers see Appendix 1 . The entire, fully resolved tree with detailed bootstrap support values is available as Appendix 2.

Tribe Thelotremateae forms a large, monophyletic, well-supported clade including the genera Chapsa, Chroodiscus, Leucodecton, and Thelotrema (Figs 7-9). The latter three are monophyletic except Thelotrema petractoides, whereas Chapsa s.lat. is polyphyletic and can be divided into four clades (Fig. 7) depending on the criteria used to recognize each clade (branch length and support): Chapsa s.str., including the type species, C. indica; the C. laceratula clade (Chapsa 2), with Topeliopsis-like apothecia, the C. astroidea clade (Chapsa 3), and the C. dilatata clade (Chapsa 4). Species of Chapsa s.lat. also appear in other clades, such as C. platycarpa in the Wirthiotrema clade (see 
Fig. 8

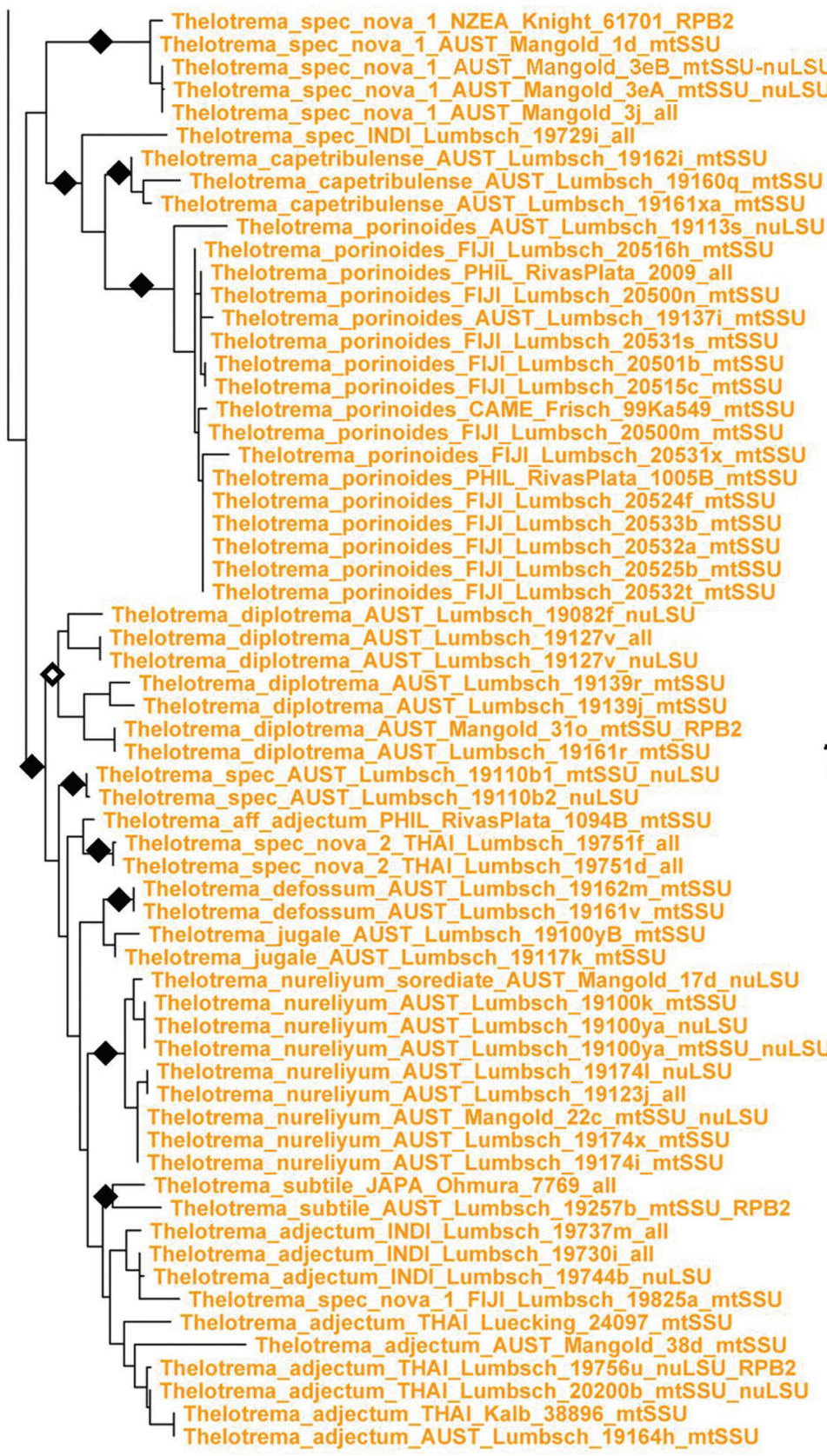

Figure 9. Detailed topology of the Thelotrema clade p.p. (subfamily Graphidoideae tribe Thelotremateae p.p.). Genus level clades are highlighted. Bootstrap support is indicated as black $(90 \%$ and higher) and black-and-white (70\% and higher) symbols. For specimen information and GenBank numbers see Appendix 1. The entire, fully resolved tree with detailed bootstrap support values is available as Appendix 2. 
above; Fig. 6) and C. leprieurii in tribe Ocellularieae (see below; Fig. 12). Thelotrema s.str. is currently the most well-represented clade in terms of sequenced species and geographic cover (Figs 8-9); it shows a well-resolved phylogenetic structure, with $T$. gallowayanum, T. conveniens, T. oleosum and $T$. porinaceum forming supported basal branches in the genus (Fig. 8). All have very narrow pores with the ascomata resembling those of Leucodecton compunctellum and certain Ocellularia s.lat. species (e.g. $O$. profunda). The T. monosporum and T. lepadinum groups form a supported sister group relationship, which is remarkable since both differ markedly in morphological and anatomical features: ecorticate, white thalli and brown ascospores in the $T$. monosporum group versus corticate, yellowish thalli and colorless ascospores in the $T$. lepadinum group. These two clades also support the concept of sporomorphs, species with identical morphology that differ in ascospore type only, since the species in the $T$. monosporum group are morphologically indistinguishable and also T. suecicum (small, transversely septate ascospores) and T. lepadinum (large, muriform ascospores) agree in external morphology. Species separated chiefly by their chemistry, such as T. porinoides and T. diplotrema, are supported as separate clades (Fig. 9). The same applies to species with clear versus inspersed hymenium, such as $T$. porinoides versus $T$. aff. porinoides (Fig. 8), suggesting that secondary chemistry and hymenium inspersion are important species-level characters even if not accompanied by other morphological differences.

The next three clades (Fig. 10) are partially unsupported and their position within the backbone of the family is unresolved. Diploschistes ocellatus, which differs from Diploschistes s.str. in chemistry (norstictic acid) and morphology (apothecia lecanoroid) is here not supported as part of the latter genus (see above; Fig. 6). The Leptotrema clade, which includes the genera Leptotrema and Reimnitzia, had been previously assigned to tribe Ocellularieae (Rivas Plata et al. 2012a) but is here not supported as part of that tribe, although it usually clusters at the base of the latter. The Acanthothecis clade, including the type species, $A$. hololeucoides, is not well-supported and also includes two species previously assigned to Topeliopsis but with a morphology similar to Acanthothecis, T. darlingtonii and T. elixii. This clade requires further study.

The last clade represents the large tribe Ocellularieae (Figs 11-13). It includes most of the species traditionally assigned to Myriotrema and Ocellularia but apparently corresponds to a much larger number of genus-level clades, some of them already recognized as Fibrillithecis, Melanotrema, Redingeria, Rhabdodiscus, and Stegobolus (Frisch et al. 2006) and others, such as Compositrema, Glaucotrema, and Rhabdodiscus, established recently as part of a detailed study of this clade (Rivas Plata et al. 2012b). The residual Myriotrema and Ocellularia as defined by Frisch et al. (2006) are still highly polyphyletic. Myriotrema can be divided into Myriotrema s.str., the M. album group (for which the name Ocellis is available), and the M. glaucophaenum group (recently separated as Glaucotrema). Ocellularia forms a large clade here named Ocellularia s.lat. (Figs 12-13) but also several smaller clades more closely related to Myriotrema s.lat., such as $O$. conformalis, $O$. inturgescens, $O$. praestans, $O$. profunda, and $O$. pyrenuloides (Fig. 11). Stegobolus s.lat. is divided into the distantly related clades Stegobolus s.str. (ascomata uncarbonized with thick, fuzzy proper margin) and Rhabdodiscus (asco- 
Fig. 7

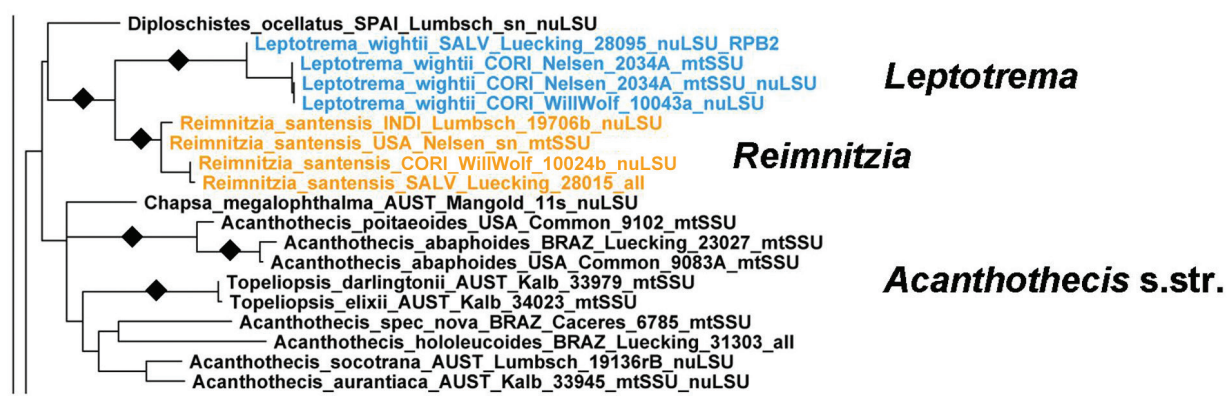

Fig. 11

Figure 10. Detailed topology of the Diploschistes ocellatus, Leptotrema, and Phaeographopsis clades (subfamily Graphidoideae). Genus level clades are highlighted. Bootstrap support is indicated as black ( $90 \%$ and higher) and black-and-white (70\% and higher) symbols. For specimen information and GenBank numbers see Appendix 1. The entire, fully resolved tree with detailed bootstrap support values is available as Appendix 2.

mata carbonized with thin, compact and smooth proper margin), the latter forming an unsupported sister to Ocellularia s.lat. (Fig. 11). The Ocellularia s.lat. clade is highly structured, including several strongly supported subclades with homogeneous morpho-chemical features (Figs 12-13): the O. terebrata group with psoromic acid and olive-green thalli; the $O$. wirthii group with psoromic acid and white thalli; the $O$. baileyi group with nornotatic acid; the $O$. microstoma group (for which the name Macropyrenium is available) with large, annulate ascomata and large, muriform ascospores, but variable chemistry; the $O$. bahiana group (for which the name Stigmagora is available) with often grainy thalli due to columnar clusters of crystals, an often irregular pseudocolumella, and protocetraric acid as predominant secondary compound; the $O$. perforata group with small, often myriotremoid ascomata and psoromic and protocetraric acid or no substances; the $O$. dolichotata group, lacking substances but with large, transversely septate ascospores; and the $O$. eumorpha group, with large ascomata and ascospores and hypoprotocetraric acid. Ampliotrema, with ecolumellate, often pigmented ascomata, inspersed hymenium, and protocetraric acid, appears as a paraphyletic residual basal to the O. eumorpha clade and Ocellularia s.str. The latter is unsupported but always monophyletic and chiefly includes species with pigmented medulla and hypoprotocetraric or nornotatic acid or cinchonarum or other unknowns. Gyrotrema is nested within Ocellularia s.str., although its chroodiscoid ascomata are quite different from the ocellularioid ascomata of the other species. Another gyrotremoid-stegoboloid species, $O$. percolumellata, is also nested in this clade. Perhaps the most unexpected surprise of this study is the supported placement of Chapsa leprieurii within Ocellularia s.lat.; except for the corticate, olive-brown thallus, this species agrees with Chapsa s.lat. in ascomata features.

Of the 428 species included in this analysis, 185 (42\%) are represented by two or more (up to 21 in the case of Thelotrema lepadinum) OTUs (total of 658 out of 922 
Fig. 10

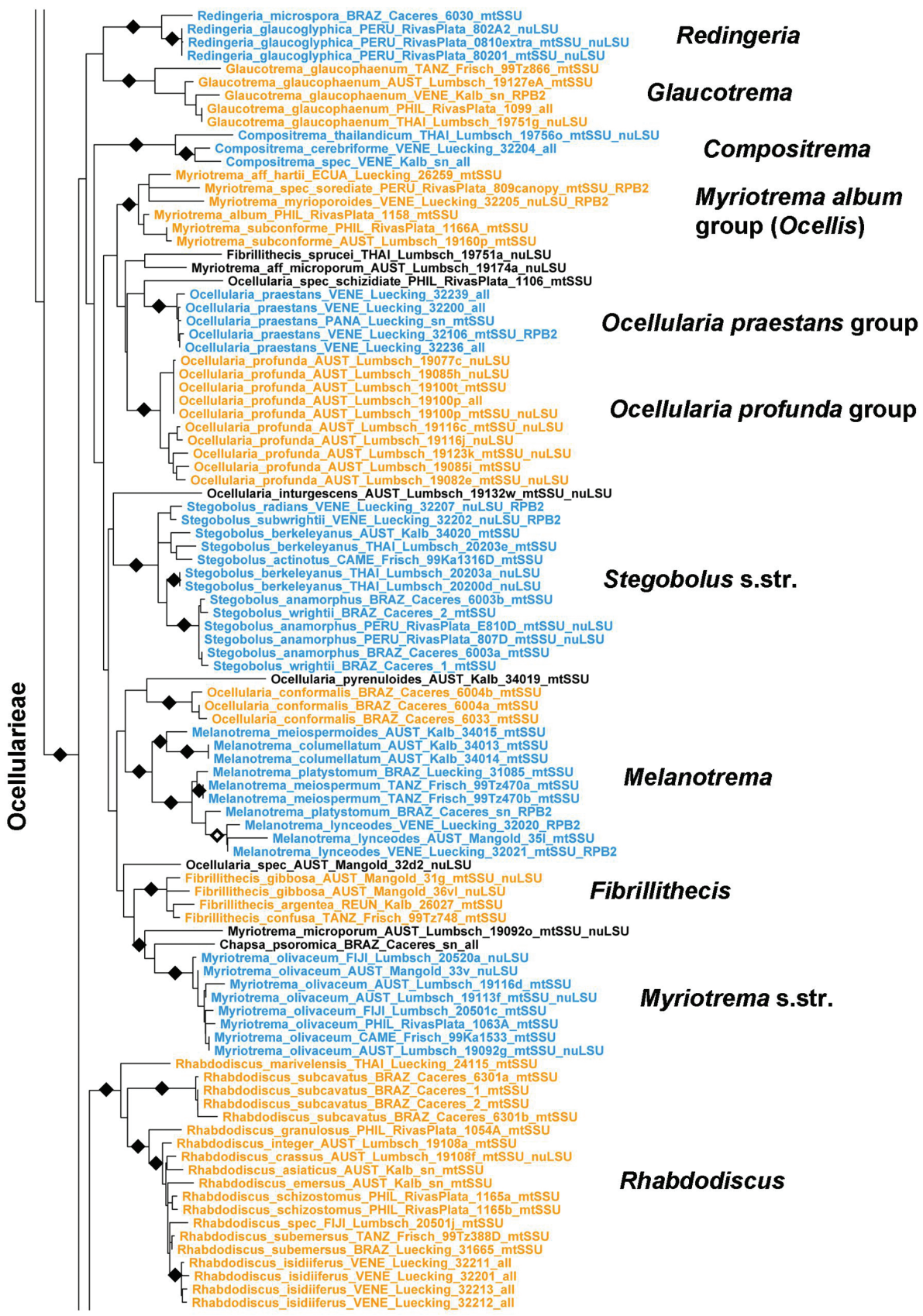

Fig. 12

Figure I I. Detailed topology of the Myriotrema s.lat. clade and relatives (subfamily Graphidoideae tribe Ocellularieae p.p.). Genus level clades are highlighted. Bootstrap support is indicated as black $(90 \%$ and higher) and black-and-white (70\% and higher) symbols. For specimen information and GenBank numbers see Appendix 1 . The entire, fully resolved tree with detailed bootstrap support values is available as Appendix 2. 
Fig. 11

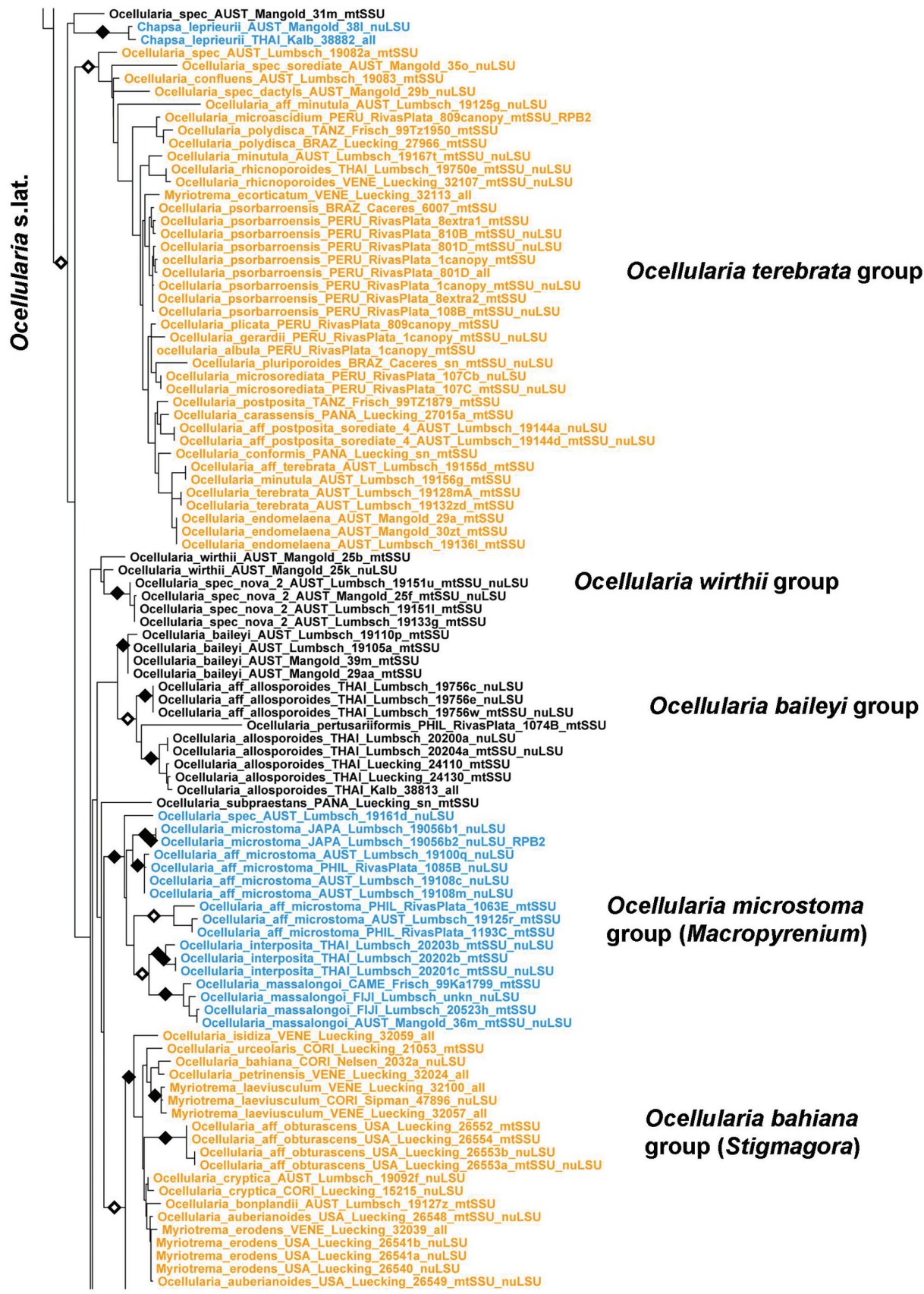

Fig. 13

Figure 12. Detailed topology of the Ocellularia s.lat. clade p.p. (subfamily Graphidoideae tribe Ocellularieae p.p.). Genus level clades are highlighted. Bootstrap support is indicated as black ( $90 \%$ and higher) and black-and-white (70\% and higher) symbols. For specimen information and GenBank numbers see Appendix 1 . The entire, fully resolved tree with detailed bootstrap support values is available as Appendix 2. 
Fig. 12

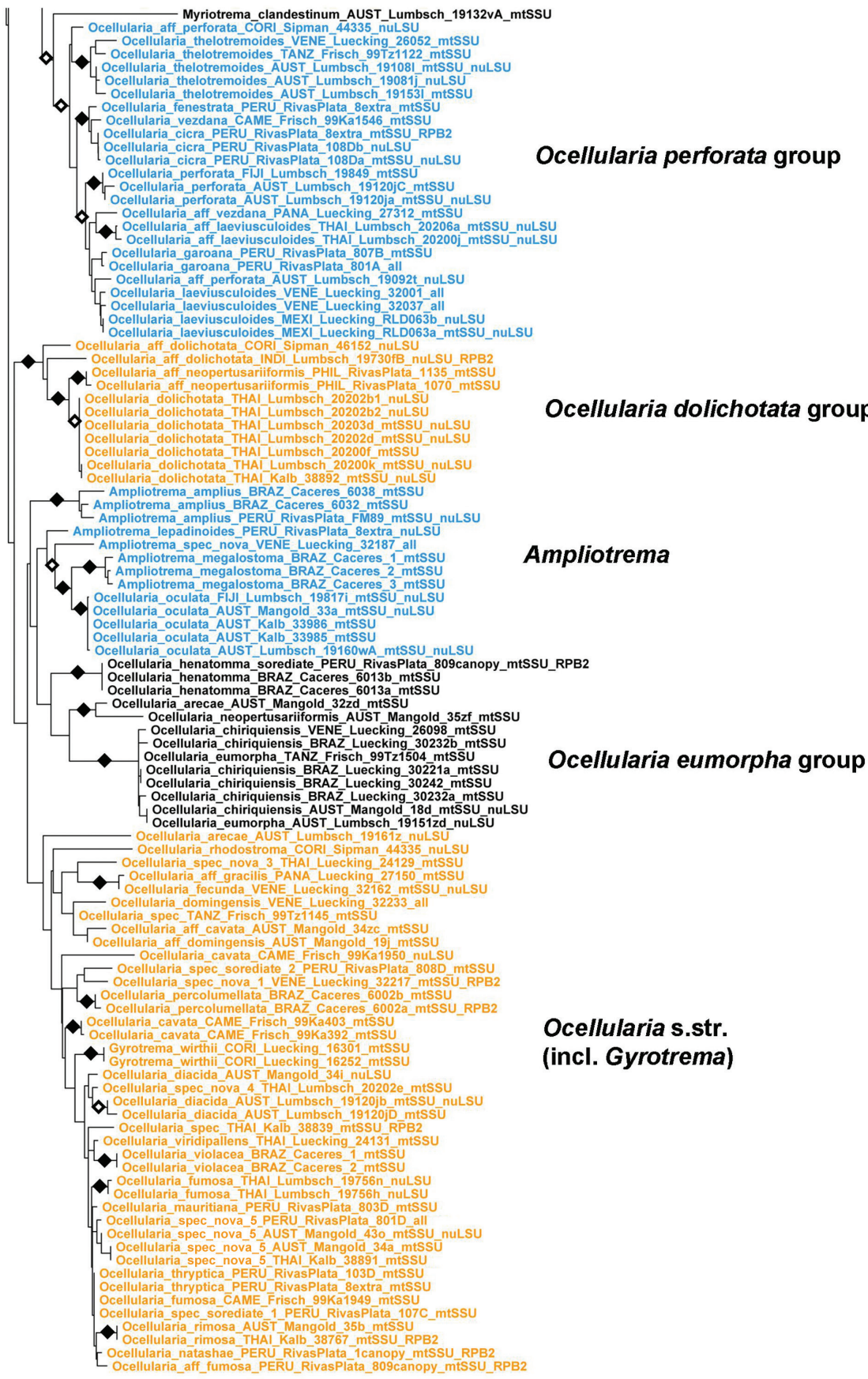

Figure 13. Detailed topology of the Ocellularia s.lat. clade p.p. (subfamily Graphidoideae tribe Ocellularieae p.p.). Genus level clades are highlighted. Bootstrap support is indicated as black ( $90 \%$ and higher) and black-and-white (70\% and higher) symbols. For specimen information and GenBank numbers see Appendix 1 . The entire, fully resolved tree with detailed bootstrap support values is available as Appendix 2. 
OTUs), providing a base for a first test of species circumscriptions. The identifications used in this analysis are based on critical cross-examination of all available material including comparison to authentic type specimens, meaning that specimens bearing the same name were found to be morphologically identical. Of the 185 species with more than one sample, 148 (80\%) were monophyletic; 20 were paraphyletic, and 17 were polyphyletic. There are several reasons to explain species-level paraphyly, such as insufficient resolution in closely related species complexes, especially in such a large phylogeny where terminal clades suffer from the effect of gap-rich alignment portions. Also, incomplete lineage sorting could cause paraphyly. Polyphyly can be explained by incomplete and non-overlapping gene sampling between OTUs of the same species, as well as incorrect species concepts suggesting (semi-)cryptic species. In the present case, two cases of paraphyly (Hemithecium implicatum, Ocellularia wirthii) and eleven cases of polyphyly (Diorygma pruinosum, Glyphis substriatula, Leucodecton glaucescens, Melanotrema platystomum, Ocellularia aff. microstoma, Ocellularia arecae, Ocellularia cavata, Ocellularia fumosa, Stegobolus berkeleyanus, Topeliopsis subdenticulata, Wirthiotrema glaucopallens) can be explained by incomplete gene sampling, e.g. mtSSU available for one OTU of a species and nuLSU for another, but not both for the same OTU. Another 12 cases of paraphyly (Chapsa leprocarpa, Clandestinotrema leucomelaenum, Fibrillithecis gibbosa, Leucodecton phaeosporum, L. subcompunctum, Myriotrema erodens, Ocellularia auberianoides, O. chiriquiensis, O. eumorpha, Platythecium leiogramma, Stegobolus anamorphus, S. wrightii) are potentially explained by insufficient resolution at the terminal clade level or incomplete lineage sorting or a combination of both. This leaves six cases of paraphyly (Fissurina pseudostromatica, Ocellularia diacida, Pallidogramme chlorocarpoides, Sarcographa ramificans, Thecaria montagnei, Thelotrema adjectum) and another six of polyphyly (Fissurina aggregatula, F. marginata, Glyphis cicatricosa, Graphis scripta, Topeliopsis acutispora, Topeliopsis decorticans) that cannot be explained by these causes and thus appear to indicate issues with current species circumscriptions.

The species level approach also allowed for testing the existence of widely distributed, intercontinental, pantropical, and cosmopolitan species. Of the 148 monophyletically resolved species, based on the available molecular data, two were confirmed as cosmopolitan taxa (the closely related sister species Thelotrema lepadinum and $T$. suecicum), 20 as pantropical (Dyplolabia afzelii, Glaucotrema glaucophaenum, Graphis caesiella, Leucodecton occultum, Melanotrema lynceodes, Ocellularia albocincta, $O$. cryptica, O. rhicnoporoides, O. thelotremoides, Phaeographis alcicornis, P. intricans, $P$. lecanographa, P. lobata, P. platycarpa, Platygramme caesiopruinosa, Reimnitzia santensis, Sarcographa labyrinthica, Thecaria quassiicola, Thelotrema monosporoides, T. pachysporum), four as at least Gondwanan (Neotropics and tropical Africa) but possibly pantropical (Clandestinotrema clandestinum, Diorygma minisporum, Ocellularia polydisca, Rhabdodiscus subemersus), four as at least paleotropical (tropical Africa, Asia and Australia) but possibly in part pantropical (Chapsa indica, Leucodecton compunctellum, Myriotrema olivaceum, Ocellularia massalongoi), and one austral (Argentina and Australia: Schizotrema schizolomum). 


\section{Discussion}

The phylogeny presented here is the most comprehensive analysis of Graphidaceae known to date compared to previous studies (Staiger et al. 2006, Mangold et al. 2008a, Rivas Plata and Lumbsch 2011). The taxon sampling, with 428 species and 908 ingroup OTUs, represents about $25 \%$ of the currently accepted species and hence provides substantial insight into the phylogenetic relationships of major clades, genera, and species. It is obvious that the evolution within this family is much more complex than reflected by previous classifications which were in use until about ten years ago (Wirth and Hale 1963, 1978; Hale 1974, 1978, 1980, 1981; Archer 1999, 2000, 2001a-d, 2002). Many of the relationships found based on molecular data would have been impossible to predict using morphological characters, such as the split into subfamilies Fissurinoideae and Graphidoideae or the polyphyly of the large genera Chapsa sensu Frisch et al. (2006), Graphis sensu Staiger (2002) and Ocellularia sensu Frisch et al. (2006a). Also, the inclusion of myriotremoid and ocellularioid lineages, such as Clandestinotrema, Cruentotrema, and Pycnotrema, within Fissurina s.lat., or the separation of morphologically similar taxa like Leptotrema wightii, Leucodecton phaeosporum, and Myriotrema laeviusculum, in unrelated lineages came quite unexpected (Rivas Plata and Lumbsch 2011, Rivas Plata et al. 2012a). Another novel clade detected in the present study is the Nadvornikia-Wirthiotrema clade, which contains the mazaedioid Nadvornikia amidst an assemblage of Thelotrema-like species that are unrelated to Thelotrema s.str. While apparently most morphological characters such as ascomata shape, excipular carbonization, and the presence of a columella, evolved multiple times within the family in distantly related clades (Rivas Plata and Lumbsch 2011), surprisingly one of the most conserved character complexes turned out to be secondary chemistry. Most clades have a predominance of particular chemosyndromes, such as stictic and norstictic acids in the tribes Graphideae and Thelotremateae and various smaller clades falling outside these tribes, as well as psoromic, protocetraric, and hypoprotocetraric acids, and cinchonarum unknowns, in tribe Ocellularieae.

The most controversially discussed higher-level changes in the classification of Graphidaceae were the inclusion of Thelotremataceae, Gomphillaceae, and Asterothyriaceae (= Solorinellaceae) in this family (Aptroot 2012; Hodkinson 2012, Rivas Plata et al. 2012a; Sipman et al. 2012). The non-monophyly of Graphidaceae versus Thelotremataceae was already indicated in early phylogenetic studies (Staiger et al. 2006) and later confirmed by Mangold et al. (2008a). The current, much larger dataset clearly supports the conclusion that Graphidaceae and Thelotremataceae cannot be separated at the family level. In order to maintain the name Thelotremataceae, it would have to be restricted to tribe Thelotremateae, which would require to establish several separate families for tribes Graphideae and Ocellularieae, as well as for a number of smaller clades. Since the only argument separating the two families historically was ascomata shape (round in Thelotremataceae versus lirellate or pseudostromatic in Graphidaceae), a classification restricting the name Thelotremataceae to tribe Thelotremateae would be misleading and would be an effort to maintain a well-known 
name, rather than reflecting a scientific advance. In the light of multiple evolution of ascomata types in different clades, merging the two families and instead delimiting infrafamily-level clades reflects the phylogenetic relationships much better.

A more difficult issue is the inclusion of Gomphillaceae and Asterothyriaceae within Graphidaceae. At first glance, this appears to be a purely phylogenetic requirement when applying the concept of strict monophyly. According to Aptroot (2012), Graphidaceae could technically be maintained as paraphyletic residual giving origin to a monophyletic Gomphillaceae (including Asterothyriaceae and Solorinellaceae). The problem of paraphyly is controversely discussed and no widely accepted solution has been proposed (Podani 2010, Hörandl and Stuessy 2010). However, the topology of the three clades proposed as subfamilies of Graphidaceae, Graphidoideae, Fissurinoideae, and Gomphilloideae (Rivas Plata et al. 2012a) does not reflect what is widely understood as paraphyly: a comb-shaped backbone from which individual clades emerge in different positions. On the contrary, the three subfamilies form three strongly supported clades on long stem branches each, and multigene studies show strong support for Fissurinoideae and Gomphilloideae being sister to each other and together sister to Graphidoideae (Baloch et al. 2010, Rivas Plata et al. 2012a, b, Nelsen et al. 2012). Therefore, splitting Fissurinoideae and the more closely related Gomphilloidae at the family level while keeping Fissurinoideae and the more distantly related Graphidoideae in a single family Graphidaceae would not create a paraphyletic taxon but would strongly disagree with the phylogenetic relationships of these taxa. Another alternative would be the recognition of three families, Gomphillaceae, Fissurinaceae, and Graphidaceae, as suggested by Hodkinson (2012). However, such a classification would not actually solve the dilemma of the apparent discrepancy between molecular phylogeny and morphological character evolution, since it would separate two clades, Fissurinoideae and Graphidoideae, at the family level with virtually no phenotypic character supporting such a separation.

One criterion that could be used to compare the alternative classifications is information content. Obviously, merging all clades into one family has the information content zero at the family level. Therefore, splitting them into three families makes only sense if the information content is greater than zero. This can be tested by using a pairwise comparison: assuming that Gomphilloideae (GO) are morphologically distinct from both Fissurinoideae (FI) and Graphidoideae (GR), whereas the latter two are not distinguishable, the pairwise comparison would result in two comparisons that are informative ( $\mathrm{GO}$ versus $\mathrm{FI}$ and $\mathrm{GO}$ versus $\mathrm{GR}$ ) and one comparison that is not informative (FI versus GR). Setting informative pairwise comparisons to +1 and noninformative to -1 , the total would be +1 , thus greater than zero, which would favor the 3-family solution partially suggested by Hodkinson (2012) over the 1-family solution suggested by Rivas Plata et al. (2012a). However, the distinction of Gomphillaceae from the other two families is not as straightforward as considered by Hodkinson (2012) and its inclusion within a wider Graphidaceae not as counterintuitive as it appears at first glance (Sipman et al. 2012). Gomphillaceae is largely separated from Graphidaceae by a chlorococcoid versus trentepohlioid photobiont, the anastomosing 
versus unbranched paraphyses, the thin-walled and non-amyloid versus graphidoid and amyloid ascospores, and the hyphophorous conidiomata, as well as the predominantly foliicolous growth habit (Lücking et al. 2004, Lücking 2008). However, these differences disappear when considering the entire range of variation in both families: Graphidaceae includes taxa with chlorococcoid photobiont (Diploschistes) and species with thin-walled, non-amyloid ascospores (Chroodiscus, Acanthotrema). Other groups, such as Diorygma, Dyplolabia, and Ocellularia s.lat., have at least partially anastomosing paraphyses. Hyphophores are not present in all species of Gomphillaceae and are absent in the genera Asterothyrium, Gyalidea, and Psorotheciopsis (Henssen and Lücking 2002, Lücking 2008). Many Gomphillaceae, particularly in the genera Echinoplaca and Gyalideopsis, are corticolous, and in Graphidaceae, genera such as Chroodiscus are exclusively foliicolous. In addition, both groups share important features, such as the usually zeorine, hemiangiocarpous ascomata with a strong tendency to become lobatelirellate, and the graphidoid ascus type. Therefore, considering the whole range of variation, there is no clear limit between these two families. Notably, Aulaxina was maintained in Graphidaceae by Santesson (1952) and Asterothyrium at some point was suggested to belong in Thelotremataceae and being related to Chroodiscus (Vezda and Poelt 1987; Aptroot et al. 1994). This view is also supported by the undisputed inclusion of Diploschistes in Graphidaceae, a genus that is ecologically very different from the remaining Graphidaceae and also genetically distinct, and which had been included in a separate family, Diploschistaceae, in the past (Zahlbruckner 1905). Hence we prefer to maintain a larger circumscription of Graphidaceae at this point.

Several genera currently placed in Graphidaceae have not yet been sequenced. These include Amazonotrema, Anomalographis, Anomomorpha, Diaphorographis, Gymnographopsis, Kalbographa, and Sarcographina (Staiger 2002, Lücking 2007, Kalb 2009, Rivas Plata et al. 2012a). The type of Sarcographina is unrelated to the sequenced S. glyphiza which therefore does not represent that genus. Also, the placement of Kalbographa lueckingii is doubtful since this species is morphologically and chemically closer to Phaeographis dendritica that to Kalbographa s.str. We therefore consider Kalbographa as of uncertain phylogenetic placement. Most of these genera have thin-walled ascospores different from most Graphidaceae but similar to, for example, Phaeographopsis. Since the latter forms a single clade with unresolved position, we also anticipate these unsequenced genera to represent further separate clades within the family. Anomomorpha is expected to be closely related to Platythecium str., since it shares morphological and chemical characteristics with that genus (Staiger 2002).

\section{Clades and taxa: progress and problems}

\section{Subfamily Fissurinoideae}

This subfamily currently includes six accepted genera. The core genus, Fissurina, includes more than 70 known species (Staiger 2002, Lücking, in prep.) and is highly 
polyphyletic, as obvious from more than half of the species sequenced. The largest, supported clade is centered around the type species, F. dumastii. Another large clade includes predominantly pseudostromatic species centered around F. pseudostromatica; for this clade, the name Medusulina is potentially available, but more species need to be sequenced to test whether this clade corresponds to pseudostromatic species only. Species with carbonized excipulum form at least three supported clades at the base of the subfamily; they differ chiefly in ascomata morphology: fissurinoid to chroodiscoid in the $F$. humilis and F. nitidescens clades and graphidoid in the F. nigrolabiata clade. Several other species of Fissurina do not cluster with these larger clades. A few more critical species require sequencing and detailed morpho-anatomical studies are necessary to elucidate whether all these clades can be recognized as separate genera. For instance, species of Fissurina s.lat. partly feature warty paraphyses and also vary in ascospore amyloidity (Staiger 2002) and these could be features distinguishing between clades.

Clandestinotrema is strongly supported as a monophyletic clade, distinguished from other taxa in this subfamily by the whitish, often loosely corticate or ecorticate thallus and ocellularioid, usually carbonized and often columellate ascomata. The taxonomy of this genus is well-resolved (Rivas Plata et al. 2012a, Sipman et al. 2012), but a few more of the currently accepted 12 species need to be sequenced to confirm monophyly of this clade. There is some indication that species with pore-like versus broadly open apothecia form two subclades that each might deserve genus or subgenus rank, but more sequences are required to test this assumption. A peculiar character shared with Cruentotrema, Dyplolabia, and several species of Fissurina, are the astrothelioid ascospores, which also help to distinguish this genus from similar species in Melanotrema and Ocellularia s.lat. (Rivas Plata and Lumbsch 2011).

Cruentotrema and Dyplolabia are two very closely related genera, although morphologically quite disparate, being either chroodiscoid with bright red medullary pigment or in the latter graphidoid with thick white pruina containing lecanoric acid (Kalb and Staiger 2000; Rivas Plata and Lumbsch 2011; Rivas Plata et al. 2012a). Each genus currently contains three species and two species each have been sequenced. In the best-scoring ML tree, Cruentotrema appears nested within Dyplolabia, but without support, and $\mathrm{SH}$ testing performed on a subset of the data including the Cruentotrema-Dyplolabia clade and its sister group does not reject the possibility of both genera being monophyletic (results not shown). Considering the morphological differences between the two genera and the infrageneric uniformity within each of them, non-monophyly seems indeed unlikely and we are planning sequence additional loci to elucidate the relationships of these genera. However, this could be an ideal group to test the potential effect of incomplete lineage sorting on incongruence between gene phylogenies and actual taxon-level lineages.

The recently described, monospecific genus Enigmotrema is very similar to Cruentotrema but its apothecia remain closed for a long time and are bright red from the outside, resembling the pyrenocarpous lichen Pyrenula cruenta (Sipman et al. 2012). Inspite of its similarities with Cruentotrema, the genus clusters outside the Cruentotrema-Dyplolabia clade and appears more closely related to the Fissurina pseudostro- 
matica clade. Nested within this clade is another monospecific genus, Pycnotrema, which resembles species of Myriotrema with its small, rounded apothecial pores (Rivas Plata et al. 2012a). Its nested position within the Fissurina pseudostromatica clade needs to be examined further.

\section{Subfamily Graphidoideae: tribe Graphideae}

This is the largest clade within the family, with possibly over 600 species. It includes the bulk of the former Graphidaceae with lirellate ascomata, with the exception of Fissurina s.lat., Carbacanthographis, and Acanthothecis. The major clades within this tribe correlate largely with ascospore type (hyaline-amyloid versus brown-hemiamyloid), whereas characters such as excipulum carbonization play a minor role, as shown by the inclusion of species of Hemithecium in either Graphis or Allographa. Thallus morphology also appears to be a good predictor of clade relationships, with white, strongly crystalline thalli characteristic of Graphis and Allographa, ecorticate thalli found mostly in the Diorygma-Thalloloma clade, and olive-green to yellow-brown thalli often lacking crystal clusters in Glyphis and the Phaeographis s.lat. clade. Graphideae are divided into two genetically distinct clades, one corresponding to Graphis s.str. and the other to all other taxa. The genetic uniqueness of Graphis s.str. was only recently established (Rivas Plata et al. 2011, Berger et al. 2011). A large number of species previously included in the revised concept of Graphis sensu Staiger (2002) turned out to belong in a separate genus, Allographa, which is more closely related to the remaining Graphideae. A formal reclassification reflecting this phylogeny has not yet been presented since species with uncarbonized excipulum previously separated in Hemithecium also fall into either Graphis or Allographa and more species of Hemithecium, including its type, need to be sequenced in order to correctly reallocate them. Rivas Plata et al. (2011) already showed that Hemithecium sensu Staiger (2002) was highly polyphyletic and formed at least five unrelated clades. Two of them clustered with either Graphis or Allographa, whereas another two fell into the vicinity of Phaeographis and are currently recognized as Malmographina and Pallidogramme, respectively (Lücking et al. 2008, Cáceres et al. 2012). The fifth clade, consisting of $H$. rufopallidum, apparently formed an isolated clade related to Allographa (Rivas Plata et al. 2011). In our current analysis, the species Platythecium grammitis fell into this clade, and re-examination of the material of $H$. rufopallidum revealed that our previous identification was incorrect: while this species was present in the voucher material, the sequenced taxon actually belonged to the superficially similar Platythecium leiogramma, thus supporting Platythecium as a separate genus.

The genus Glyphis remains a strongly supported clade within Graphideae, including species with rounded, lirellate, and pseudostromatic ascomata. However, species relationships require further study since the pseudostromatic G. cicatricosa does not appear to be monophyletic. The mazaediate genus Schistophoron, which resembles species of $\mathrm{Al}$ lographa, consistently comes out as sister to Glyphis, but lacking support. Both genera are morphologically and anatomically quite different. Diorygma and Thalloloma, two gen- 
era with similar thallus and ascomata morphology but with different chemical profiles (Staiger 2002, Kalb et al. 2004) appear to be nested within each other and most probably will have to be merged into a single genus. Supposed differences such as hamathecium structure and amyloidity (Staiger 2002, Kalb et al. 2004) do not seem to correlate with the topology found in this clade. On the other hand, Platythecium sensu Staiger (2002) appears to be polyphyletic, corresponding to two morphologically and chemically distinct clades.

The remaining genera all have brown, hemiamyloid ascospores and consistently form a monophyletic clade (Lücking et al. 2011, Rivas Plata et al. 2011, Cáceres et al. 2012), although support was lacking in the present analysis. However, genus-level relationships and genus delimitation within this clade are in need of major revision. Most of the currently accepted genera (Staiger 2002) are para- or polyphyletic at some level, whereas supported monophyletic clades have not been recognized at genus level. Among the latter are the Phaeographis lobata-lecanographa group and the $P$. intricans group, for which the name Creographa is potentially available. Platygramme s.str. is monophyletic but its delimitation towards Phaeographis s.lat. is uncertain, since species with distinctly carbonized labia, such as $P$. impudica, appear elsewhere in this clade. Most other genera, such as Halegrapha, Malmographina, Pallidogramme, Phlegographa, and Thecaria, show a similar pattern, with the type species and its close relatives forming monophyletic clades but nested within a paraphyletic Phaeographis s.lat. grade. Thecaria montagnei is apparently not close to the type species, T. quassiicola, and the generic name Pliariona is potentially available for this species. Leiorreuma and Sarcographa appear both non-monophyletic, with the core groups forming a single clade in a derived position. Phaeographis s.str. thus far appears to be restricted to the type species, $P$. dendritica, which is characterized by its white, ecorticate thallus and non-pruinose ascomata. Most species of Phaeographis s.lat. have a corticate thallus and pruinose ascomata, and the name Ectographis is potentially available for these. However, many more species need to be sequenced in these groups to establish a solid phylogeny and generic concept for Phaeographis and its allies. The most important characters separating clades within this assemblage are ascomata organization (solitary versu pseudostromatic), disc visibility (exposed versus concealed), hymenium inspersion (inspersed versus clear), and excipular and hypothecium carbonization (uncarbonized versus carbonized). On their own, these clades appear to be quite distinctive; however, exactly the same level of variation is found in Graphis and Allographa, two clades that form single genera including between 100 and over 200 species each, and therefore, it would not appear illogical to actually merge Creographa, Ectographis, Halegrapha, Leiorreuma, Malmographina, Pallidogramme, Phaeographis s.str., Phlegographa, Platygramme, Pliariona, Sarcographa, and Thecaria, into a single, large genus Phaeographis.

A unique, novel lineage was detected clustering between Platythecium and Allographa. The new genus, Mangoldia, from Australia combines a Phaeographis morphology with Graphis type hymenium and ascospores, a previously unknown combination of characters (Lücking et al. 2012). 


\section{Subfamily Graphidoideae: Acanthothecis clade}

This clade includes species of Acanthothecis s.str. with weakly corticate or ecorticate thallus and rounded ascomata, as well as some corticolous species currently classified in Topeliopsis: T. darlingtonii and T. elixii. The morphology of these taxa is quite similar and most likely they should all be included within Acanthothecis, although not all have the apically spinulose paraphyses and periphysoids characteristic of that genus (Staiger and Kalb 1999, Staiger 2002). Species of Acanthothecis s.lat. with corticate thallus and lirellate ascomata do not belong here but cluster next to Carbacanthographis.

\section{Subfamily Graphidoideae: Acanthotrema clade}

Acanthotrema is a small genus of four species characterized by a corticate thallus, chroodiscoid ascomata, and thin-walled ascospores of the Chroodiscus type (Rivas Plata et al. 2010b). This genus, which is found on shaded tree trunks in the lowland rain forest, appears rather isolated within the family on a very long branch and its exact position remains unresolved. Depending on taxon sampling, it either clusters close to tribe Thelotremateae or the Diploschistes clade (Papong et al. 2009, Rivas Plata et al. 2012a), but always lacking support for either placement.

\section{Subfamily Graphidoideae: Carbacanthographis clade}

This clade includes two strongly supported genus-level clades: Carbacanthographis and Acanthothecis 2, in addition to a further species of Carbacanthographis forming an unsupported sister clade. Carbacanthographis has graphidoid ascomata but is not closely related to Graphis and allies, whereas Acanthothecis 2 has fissurinoid-hemithecioid ascomata, while not being closely related to either Fissurina or Hemithecium (Staiger and Kalb 1999, Staiger 2002). Carbacanthographis currently includes close to 20 species, but only two have been sequenced; molecular data for more species are required to confirm monophyly of this genus. Only one species of Acanthothecis falling into this clade, $A$. peplophora, has been sequenced so far, but its morphology suggests that this clade includes species of Acanthothecis with corticate thallus and striate lirellae, such as the widespread tropical A. subclavulifera (Staiger and Kalb 1999, Staiger 2002). This clade will eventually require a new genus name; it is not closely related to Acanthothecis s.str., based on $A$. hololeucoides.

\section{Subfamily Graphidoideae: Diploschistes clade}

Diploschistes is a medium-sized genus of about 30 currently accepted species (Lumbsch 1989, Guderley and Lumbsch 1996, Lumbsch and Elix 2003, Rivas Plata et al. 2010b). 
It is unique in the family in having a chlorococcoid photobiont and due to its ecology and chemistry, forming well-developed, thick thalli usually on soil or rock surfaces or sometimes on bryophytes with the depsides gyrophoric, lecanoric, and diploschistesic acids as main compounds. The genus usually clusters close to tribe Thelotremateae but this position is not supported. The very long stem branch together with the very short terminal branches suggest that this genus radiated very recently, which is remarkable considering that it is cosmopolitan in distribution. The placement of the norstictic acid containing, lecanoroid D. ocellatus requires additional studies (see below). Another genus supposedly related to Diploschistes, Ingvariella (Guderley et al. 1997), has been shown to belong in Stictidaceae (Fernández-Brime et al. 2011).

\section{Subfamily Graphidoideae: Diploschistes ocellatus clade}

Diploschistes ocellatus differs from other species of Diploschistes in the lecanoroid ascomata and norstictic acid as major compound in the thallus. Its phylogenetic position is unresolved, although it usually clusters close to or at the base of the Diploschistes clade (Fernández-Brime et al. 2011). Additional loci need to be sequenced to address monophyly of Diploschistes as currently circumscribed.

\section{Subfamily Graphidoideae: Heiomasia clade}

This clade includes a single genus with two known species, Heiomasia seaveyorum and H. sipmanii. It was recently described and both species are only known with isidioid propagules but lack ascomata (Nelsen et al. 2010). Additional loci need to be sequenced to address the relationships of this isolated clade but it might well represent a relict clade with no close extant relative, similar to the case of Phaeographopsis.

\section{Subfamily Graphidoideae: Phaeographopsis clade}

Phaeographopsis is a lowland rain forest genus. It resembles species of Diorygma in the green, ecorticate thallus and pruinose, lirellate ascomata, but differs in the thinwalled, dark brown ascospores which accumulate above the hymenium and form weakly developed mazaedia (Aptroot et al. 1997, 2007, Kalb 2004, Lücking and Rivas Plata 2008). The genus, which includes two species, consistently clusters close to Diploschistes but without support; therefore its phylogenetic position is unresolved. The unique morphological features and long branch suggest this to represent another relict taxon in Graphidaceae. 


\section{Subfamily Graphidoideae: Topeliopsis clade}

This clade was previously included in tribe Thelotremateae (Rivas Plata et al. 2012a) but with this larger dataset falls outside that tribe. It includes the bulk of taxa with topeliopsidoid-schizotremoid ascomata, that is, apothecia with layered (striate) excipulum; many species occur in the southern Hemisphere or are tropical-montane and often grow on bryophytes (Frisch and Kalb 2006, Mangold et al. 2008b, Lumbsch et al. 2010). Within this clade, both Schizotrema s.str. (excipulum carbonized, ascomata erumpent over tree bark) and Topeliopsis s.str. (excipulum non-carbonized, ascomata mostly sessile on bryophytes) form monophyletic and well-supported clades. Melanotopelia (excipulum carbonized, ascomata mostly sessile on bryophytes) is also potentially monophyletic, but only one of the four currently accepted species has been sequenced so far. Two species of Schizotrema s.lat. from separate clades and their relationships need to be studied further. Two further species of Topeliopsis cluster within to Acanthothecis s. str.

\section{Subfamily Graphidoideae: Wirthiotrema clade}

This well-supported clade includes species previously classified in Thelotrema but apparently not related to the latter genus. In addition, the mazaediate Nadvornikia hawaiiensis is nested within this clade. Three supported subclades can be distinguished: a clade consisting of Thelotrema bicinctulum, a corticate species morphologically intermediate between Thelotrema and Myriotrema; a clade consisting of Chapsa platycarpa and Thelotrema leucophthalmum; a clade consisting of Myriotrema peninsulae, Leudodecton expallescens, and Nadvornikia hawaiiensis; and a well-supported clade representing the recently segregated genus Wirthiotrema (Rivas Plata et al. 2010a). This entire clade will be treated in detail in a separate, forthcoming paper.

\section{Subfamily Graphidoideae: tribe Thelotremateae}

This tribe is well-supported in all analyses and contains four currently accepted genera, including a monophyletic Chroodiscus forming sister to the remaining genera, a monophyletic Leucodecton, and a monophyletic Thelotrema s.str., all strongly supported. These three genera differ consistently in ascomata morphology: Chroodiscus has chroodiscoid ascomata lacking periphysoids, Leucodecton also lacks periphysoids but its ascomata are mostly myriotremoid-porinoid, and Thelotrema features mostly lepadinoid ascomata with periphysoids and double margin (proper excipulum free). On the other hand, the genus Chapsa, with chroodiscoid ascomata and periphysoids, is polyphyletic, forming several well-supported clades. There is some correlation with morphological features in these clades but these need to be studied further, and this clade is currently being analyzed in a separate study (Parnmen et al. 2012). Also, several species of Chapsa s.lat. fall outside this tribe, such as C. platycarpa and C. leprieurii. 
The well-supported placement of the latter as sister to Ocellularia s.lat. is another surprising find of this study.

\section{Subfamily Graphidoideae: Leptotrema clade}

This clade was previously included in tribe Ocellulariae as basal sister group to Ocellularieae s.str. (Rivas Plata and Lumbsch 2011, Rivas Plata et al. 2012a), but the larger dataset analysed here does not support this relationship, although the clade consistently comes out as sister to Ocellularieae. The clade includes two genera, Leptotrema and Reimnitzia, which agree in general thallus morphology and ascus and ascospore type (Frisch et al. 2006a), but differ in the myriotremoid versus chroodiscoid ascomata.

\section{Subfamily Graphidoideae: tribe Ocellularieae}

This tribe is being treated in detail in a parallel paper based on roughly the same dataset (Rivas Plata et al. 2012b) and therefore is not further discussed here. It includes well over 300 species currently assigned to up to 12 genera: Ampliotrema, Compositrema, Fibrillithecis, Glaucotrema, Gyrotrema, Melanotrema, Myriotrema, Ocellis, Ocellularia s.lat., Redingeria, Rhabdodiscus, and Stegobolus. However, several more lineages exist deserving generic status and some genera appear to be nested within others, such as Gyrotrema within Ocellularia s.str. We expect that a more complete dataset in terms of complete sampling of genes will help to resolve this clade. Very unexpected is the placement of Chapsa leprieurii in Ocellularia s.lat.; this species has Chapsa-like ascomata with lateral periphysoids, a character otherwise absent in the entire Ocellularieae. Yet, its placement is supported by several sequences representing all three genes from two different specimens. We have no explanation for this placement, other than recognizing it as yet another remarkable case of parallel evolution in Graphidaceae (Rivas Plata and Lumbsch 2011).

\section{Species delimitations in Graphidaceae}

Although the sampling for this study was focused in targeting as many species as possible, with generally few repeats per species, the data allows a first approach in testing species concepts. The identifications made for the purpose of this study already represent a refined species concept as result of cross-examination of all available material and comparison with authentic type specimens. Thus, for example, previous identifications made using a more coarse species concept had already been corrected prior to this analysis, particularly in the genera Thelotrema and Ocellularia s.lat. (e.g. Rivas Plata et al. 2012b). Still, of the 185 species represented by at least two (and up to 21) OTUs, 37 turned out to be paraphyletic or polyphyletic. Of these, 12 cases can be explained by insufficient 
gene sampling (non-overlapping genes for different OTUs of the same species). Another 13 cases can potentially be resolved by analysing the corresponding clades separately, since for terminal clades, gap-rich regions caused by aligning a multitude of sequenced across a large group of species will mask the phylogenetic signal contained in these regions. Thus, the remaining 12 out of 185 species appear to present problems in terms of species concepts. These may either represent cases of too narrow species concepts (e.g. Pallidogramme chlorocarpoides versus $P$. chrysenteron, which differ only in ascospore size and number) or cases of cryptic species (e.g. Fissurina marginata, O. diacida, Thelotrema adjectum). In some cases, such as Glyphis cicatricosa and Graphis scripta, the sequenced material could not be completely tested, but available data suggest that more than one species are hidden under these names. For example, G. cicatricosa includes forms with different ascomata configuration (rounded versus lirellate-stellate), which might explain the presence of more than one species. In the case of Graphis scripta, a recent revision (Neuwirth and Aptroot 2012) already divided this taxon into at least four species, and the molecular data seem to confirm this view. Other species, such as Fissurina aggregatula versus $F$. pseudostromatica, or taxa such as S. ramificans and Thecaria montagnei, include specimens with subtle morphological differences and these are obviously not yet fully understood. Notable is the case of Topeliopsis acutispora versus T. decorticans, two morphologically similar species that have quite different ascospores; the clade including these species obviously requires more scrutinity. In spite of these unresolved cases, it however seems that the combination of molecular analysis and critical revision of phenotype characters has improved the species concept in Graphidaceae considerably.

It was generally assumed that many lichens have a wide geographic distribution, much wider than vascular plants (Jørgensen 1983, Galloway 1988, Tibell 1994, Lücking 2003, Feuerer and Hawksworth 2007). However, molecular phylogenetic studies have challenged this view for many taxa (Tehler et al. 2009, 2010, Del Prado et al. 2011, Molina et al. 2011), and Graphidaceae are no exception. While previous studies assumed a proportion of 30-50\% intercontinental, pantropical, or even cosmopolitan species (Wirth and Hale 1963, 1978, Hale 1974, 1978, 1981), the present analysis only confirmed 31 out of 148 monophyletic species (21\%) as belonging to one of these categories, and only 20 as pantropical. In part this is a sampling artifact, and with more sequence data available, more species, such as Leucodecton compunctellum and Myriotrema olivaceum (for which unsequenced material from the Neotropics is known), will be confirmed to have a wide distribution. However, this is probably more than counterbalanced by the large number of new species with apparently narrow distribution ranges discovered in recent, detailed inventories (Kalb 2009, Rivas Plata and Lücking 2012, Rivas Plata et al. 2012b, Sipman et al. 2012). It also appears that some of the pantropical species, such as Glaucotrema glaucophaenum, Platygramme caesiopruinosa, Thelotrema diplotrema, and T. pachysporum, exhibit a highly structured phylogeny, suggesting that these might represent species complexes with separate, (semi-)cryptic species occurring in different geographic regions. Therefore, it appears that the proportion of species with narrow distribution ranges in Graphidaceae, and in lichens in general, is much higher than previously assumed. 


\section{Acknowledgements}

This study was supported by several grants from the National Science Foundation: TICOLICHEN (DEB-0206125 to The Field Museum; PI Robert Lücking), Phylogeny and Taxonomy of Ostropalean Fungi, with Emphasis on the Lichen-forming Thelotremataceae (DEB-0516116 to The Field Museum; PI H. T. Lumbsch; Co-PI R. Lücking), Neotropical Epiphytic Microlichens - An Innovative Inventory of a Highly Diverse yet Little Known Group of Symbiotic Organisms (DEB-0715660 to The Field Museum; PI R. Lücking), and ATM - Assembling a taxonomic monograph: The lichen family Graphidaceae (DEB-1025861 to The Field Museum; PI T. Lumbsch, CoPI R. Lücking). The Caterpillar company provided funds to study lichens and other cryptogams from Panama, especially with regard to molecular approaches. The following individuals, including curators at herbaria from which type specimens were studied, are thanked for their collaboration: Teuvo Ahti, André Aptroot, Alan Archer, Alejandrina BarcenasPeña, Paulina Bawingan, Andreas Beck, Michel Benatti, Kansri Boonpragop, Othmar Breuss, William Buck, Luciana Cañez, José Luis Chaves, Philippe Clerc, Bruno Dennetiére, Pradeep Divakar, Melissa Duva, Lidia Ferraro, Alan Fryday, Martin Grube, Richard Harris, María de los Ángeles Herrera-Campos, Seppo Huhtinen, Paul Kirika, Allison Knight, James Lendemer, Marcelo Marcelli, Milagro Mata, Bruce McCune, Gregory McKee, Gerhard Neuwirth, Khwanruan Papong, Uwe Passauer, Gary Perlmutter, Rusty Russell, Noris Salazar, Michaela Schmull, Adriano Spielmann, Soili Stenroos, Arlene Tabaquero, Anders Tehler, Holger Thüs, Chandrani Wijeyaratne, Patricia Wolseley, Rebecca Yahr, and Zak Zahawi.

\section{References}

Aptroot A, Kärnefeldt I, Tibell L (1994) Discussion 6: Caliciales, Graphidales, and Teloschistales. In: Hawksworth DL (Ed) Ascomycete Systematics. Problems and Perspectives in the Nineties: 393-396. NATO ASI Series, Series A: Life Sciences, Vol. 29. Plenum Press, New York and London.

Aptroot A (2012) Dilemmas in species and genus delimitation in e.g. Graphidaceae. The 7th IAL Symposium: Lichens: From Genome to Ecosystems in a Changing World. Abstracts: 28. Ramkhamhaeng University Press, Bangkok, Thailand.

Aptroot A, Diederich P, Sérusiaux E, Sipman HJM (1997) Lichens and lichenicolous fungi from New Guinea. Bibliotheca Lichenologica 64: 1-220.

Aptroot A, Saipunkaew W, Sipman HJM, Sparrius LB, Wolseley P (2007) New lichens from Thailand, mainly microlichens from Chiang Mai. Fungal Diversity 24: 75-134.

Archer AW (1999) The lichen genera Graphis and Graphina (Graphidaceae) in Australia 1. Species based on Australian type specimens. Telopea 8: 273-295.

Archer AW (2000) The lichen genera Phaeographis and Phaeographina (Graphidaceae) in Australia. 1: Species based on Australian type specimens. Telopea 8: 461-475. 
Archer AW (2001a) The lichen genera Phaeographis and Phaeographina (Graphidaceae) in Australia 2: Phaeographina - new reports and new species. Telopea 9: 329-344.

Archer AW (2001b) The lichen genera Phaeographis and Phaeographina (Graphidaceae) in Australia 3: Phaeographis - new reports and new species. Telopea 9: 663-677.

Archer AW (2001c) The lichen genus Graphina (Graphidaceae) in Australia: new reports and new species. Mycotaxon 77: 153-180.

Archer AW (2001d) The lichen genus Graphis (Graphidaceae) in Australia. Australian Systematic Botany 14: 245-271. doi: 10.1071/SB00023

Archer AW (2002) Graphidaceae (Ascomycotina) from the Solomon Islands: new species from Guadalcanal. Mycotaxon 83: 361-367.

Archer AW (2006) The lichen family Graphidaceae in Australia. Bibliotheca Lichenologica 94: 1-191.

Archer AW (2007) Key and checklist for the lichen family Graphidaceae (lichenised Ascomycota) in the Solomon Islands. Systematics and Biodiversity 5: 9-22. doi: 10.1017/ S1477200006002040

Archer AW (2009) Graphidaceae. Flora of Australia 57: 84-194.

Baloch E, Lücking R, Lumbsch HT, Wedin M (2010) Major clades and phylogenetic relationships between lichenized and non-lichenized lineages in Ostropales (Ascomycota: Lecanoromycetes). Taxon 59: 1483-1494.

Berger SA, Stamatakis A, Lücking R (2011) Morphology-based phylogenetic binning of the lichen genera Allographa and Graphis via molecular site weight calibration. Taxon 60: $1450-1457$.

Cáceres MES, Rivas Plata E, Lücking R (2012) Malmographina, a new genus for Graphina malmei (Ascomycota: Ostropales: Graphidaceae). Lichenologist 44: 115-120. doi: $10.1017 /$ S0024282911000697

Del-Prado R, Divakar PK, Crespo A (2011) Using genetic distances in addition to ITS molecular phylogeny to identify potential species in the Parmotrema reticulatum complex: a case study. Lichenologist 43: 569-583. doi: 10.1017/S0024282911000582

Fernández-Brime S, Llimona X, Molnar K, Stenroos S, Högnabba F, Björk C, Lutzoni F, Gaya E (2011) Expansion of the Stictidaceae by the addition of the saxicolous lichen-forming genus Ingvariella. Mycologia 103: 755-763. doi: 10.3852/10-287

Feuerer T, Hawksworth DL (2007) Biodiversity of lichens, including a world-wide analysis of checklist data based on Takhtajan's floristic regions. Biodiversity and Conservation 16: 85-98. doi: 10.1007/s10531-006-9142-6

Frisch A, Kalb K (2006) The lichen genus Topeliopsis, additions and corrections. Lichenologist 38: 37-45. doi: 10.1017/S0024282905005530

Frisch A, Kalb K, Grube M (2006a) Contributions towards a new systematics of the lichen family Thelotremataceae. Bibliotheca Lichenologica 92: 1-539.

Frisch A, Kalb K, Grube M (2006b) Contributions towards a new systematics of the lichen family Thelotremataceae III. Molecular phylogeny of the Thelotremataceae. Bibliotheca Lichenologica 92: 517-539. 
Galloway DJ (1988) Plate tectonics and the distribution of cool temperate southern hemisphere macrolichens. Botanical Journal of the Linnean Society 96: 45-55. doi: 10.1111/ j.1095-8339.1988.tb00626.x

Guderley R, Lumbsch HT (1996) The lichen genus Diploschistes in South Africa (Thelotremataceae). Mycotaxon 58: 269-292.

Guderley R, Lumbsch HT, Feige GB (1997) Ingvariella, a new genus in the Thelotremataceae (lichenized Ascomycotina). Nova Hedwigia 64: 147-154.

Hale ME Jr (1974) Morden-Smithsonian Expedition to Dominica: The lichens (Thelotremataceae). Smithsonian Contributions to Botany 16: 1-46. doi: 10.5479/si.0081024X.16

Hale ME Jr (1978) A revision of the lichen family Thelotremataceae in Panama. Smithsonian Contributions to Botany 38: 1-60. doi: 10.5479/si.0081024X.38

Hale ME Jr (1980) Generic delimitation in the lichen family Thelotremataceae. Mycotaxon 11: 130-138.

Hale ME (1981) A revision of the lichen family Thelotremataceae in Sri Lanka. Bulletin of the British Museum of Natural History (Botany) 8: 227-332.

Hall TA (1999) BioEdit: a user-friendly biological sequence alignment editor and analysis program for Windows 95/98/NT. Nucleic Acids Symposium Series 41: 95-98.

Henssen A, Lücking R (2002) Morphology, anatomy, and ontogeny in the Asterothyriaceae (Ascomycota: Ostropales), a misunderstood group of lichenized fungi. Annales Botanici Fennici 39: 273-299.

Hodkinson BP (2012) An evolving phylogenetically based taxonomy of lichens and allied fungi. Opusculae Philolichenum 11: 4-10.

Hörandl E, Stuessy TF (2010) Paraphyletic groups as natural units of biological classification. Taxon 59: 1641-1653.

Jørgensen PM (1983) Distribution patterns of lichens in the Pacific region. Australian Journal of Botany Supplement 10: 43-66.

Kalb K (2004) New or otherwise interesting lichens II. Bibliotheca Lichenologica 88: 301-329.

Kalb K (2009) New taxa and new records of thelotremoid Graphidaceae. Herzogia 22: 17-42.

Kalb K, Staiger B (2000) Dyplolabia Massalongo - Monographie einer vergessenen Flechtengattung. Hoppea 61: 409-422.

Kalb K, Staiger B, Elix JA (2004) A monograph of the lichen genus Diorygma - a first attempt. Symbolae Botanicae Upsalienses 34(1): 133-181.

Katoh K, Toh M (2005) MAFFT version 5: improvement in accuracy of multiple sequence alignment. Nucleic Acids Research 33: 511-518. doi: 10.1093/nar/gki198

Kauff F, Lutzoni F (2002) Phylogeny of Gyalectales and Ostropales (Ascomycota, Fungi): among and within order relationships based on nuclear ribosomal RNA small and large subunits. Molecular Phylogenetics and Evolution 25: 138-156. doi: 10.1016/S10557903(02)00214-2

Liu YJ, Whelen S, Hall BD (1999) Phylogenetic relationships among ascomycetes: evidence from the RNA polymerase II subunit. Molecular Biology and Evolution 16: 1799-1808. doi: 10.1093/oxfordjournals.molbev.a026092

Lücking R (2003) Takhtajan's floristic regions and foliicolous lichen biogeography: a compatibility analysis. Lichenologist 35: 33-54. doi: 10.1006/lich.2002.0430 
Lücking R (2007) Kalbographa: Monografie einer unerkannten Flechtengattung. Bibliotheca Lichenologica 96: 185-192.

Lücking R (2008) Foliicolous lichenized fungi. Flora Neotropica Monographs 103: 1-866.

Lücking R (2009) The taxonomy of the genus Graphis sensu Staiger (Ascomycota: Ostropales: Graphidaceae). Lichenologist 41: 319-362. doi: 10.1017/S0024282909008524

Lücking R (2012) Predicting species richness in tropical lichenized fungi with 'modular' combinations of character states. Biodiversity and Conservation 21: 2341-2360. doi: 10.1007/ s10531-011-0217-7

Lücking R, Rivas Plata E (2008) Clave y guía ilustrada para géneros de Graphidaceae. Glalia 1: $1-41$.

Lücking R, Stuart BL, Lumbsch HT (2004) Phylogenetic relationships of Gomphillaceae and Asterothyriaceae: evidence from a combined Bayesian analysis of nuclear and mitochondrial sequences. Mycologia 96: 283-294. doi: 10.2307/3762064

Lücking R, Chaves JL, Sipman HJM, Umaña L, Aptroot A (2008) A first assessment of the Ticolichen biodiversity inventory in Costa Rica: the genus Graphis, with notes on the genus Hemithecium (Ascomycota: Ostropales: Graphidaceae). Fieldiana 46: 1-130. doi: 10.3158/0015-0746(2008)46[1:AFAOTT]2.0.CO;2

Lücking R, Archer AW, Aptroot A (2009) A world-wide key to the genus Graphis (Ostropales: Graphidaceae). Lichenologist 41: 363-452. doi: 10.1017/S0024282909008305

Lücking R, Rivas Plata E, Kalb K, Common RS, Barcenas-Peńa A, Duya MV (2011) Halegrapha (Ascomycota: Graphidaceae), an enigmatic new genus of tropical lichenized fungi dedicated to Mason E. Hale Jr. Lichenologist 43: 331-343. doi: 10.1017/S0024282911000302

Lücking R, Parnmen S, Lumbsch HT (2012) Mangoldia, a new lichen genus in the family Graphidaceae (Ascomycota: Ostropales). Phytotaxa 69: 1-5.

Lumbsch HT (1989) Die holarktischen Vertreter der Flechtengattung Diploschistes (Thelotremataceae). Journal of the Hattori Botanical Laboratory 66: 133-196.

Lumbsch HT, Elix JA (2003) The lichen genus Diploschistes (Thelotremataceae) in Australia. Bibliotheca Lichenologica 86: 119-128.

Lumbsch HT, Mangold A, Martín MP, Elix JA (2008) Species recognition and phylogeny of Thelotrema species in Australia (Ostropales, Ascomycota). Australian Systematic Botany 21: 217-227. doi: 10.1071/SB07049

Lumbsch HT, Divakar PK, Messuti MI, Mangold A, Lücking R (2010) A survey of thelotremoid lichens (Ascomycota: Ostropales) in subantarctic regions excluding Tasmania. Lichenologist 42: 203-224. doi: 10.1017/S002428290999048X

Mangold A, Martin MP, Lücking R, Lumbsch HT (2008a) Molecular phylogeny suggests synonymy of Thelotremataceae within Graphidaceae (Ascomycota: Ostropales). Taxon 57: 476-486.

Mangold A, Martín MP, Kalb K, Lücking R, Lumbsch HT (2008b) Molecular data show that Topeliopsis (Ascomycota, Thelotremataceae) is polyphyletic. Lichenologist 40: 39-46. doi: $10.1017 /$ S0024282908007366

Mangold A, Elix JA, Lumbsch HT (2009) Thelotremataceae. Flora of Australia 57: 195-420. 
Mason-Gamer RJ, Kellogg EA (1996) Testing for phylogenetic conflict among molecular data sets in the tribe Triticeae (Gramineae). Systematic Biology 45: 524-545. doi: 10.1093/ sysbio/45.4.524

Miadlikowska J, Lutzoni F (2000) Phylogenetic revision of the genus Peltigera (lichen-forming Ascomycota) based on morphological, chemical and large subunit nuclear ribosomal DNA data. Intern. Journal of Plant Science 161: 925-968. doi: 10.1086/317568

Miller MA, Pfeiffer W, Schwartz T (2010) Creating the CIPRES Science Gateway for inference of large phylogenetic trees. In: Proceedings of the Gateway Computing Environments Workshop (GCE): 1-8. New Orleans. doi: 10.1109/GCE.2010.5676129

Molina MC, Del-Prado R, Divakar PK, Sánchez-Mata S, Crespo A (2011) Another example of cryptic diversity in lichen-forming fungi: The new species Parmelia mayi (Ascomycota: Parmeliaceae). Organismic Diversity and Evolution 11: 331-342. doi: 10.1007/s13127011-0060-4

Müller J (1887) Graphideae Féeanae inclus. trib. affinibus nec non Graphideae exoticae Acharii, El. Friesii et Zenkeri e novo studio speciminum originalium expositae et in novam dispositionem ordinatae. Mémoirs de la Société Physique et d'Histoire Naturelle Genève 29(8): $1-80$.

Nelsen MP, Lücking R, Rivas Plata E, Mbatchou JS (2010) Heiomasia, a new genus in the lichen-forming family Graphidaceae (Ascomycota: Lecanoromycetes: Ostropales) with disjunct distribution in Southeastern North America and Southeast Asia. Bryologist 113: 742-751. doi: 10.1639/0007-2745-113.4.742

Nelsen MP, Lücking R, Andrew CJ, Rivas Plata E, Chaves JL, Cáceres MES, Ventura N (2012) Dismantling Herpothallon: Herpothallon antillarum (Arthoniomycetes: Arthoniaceae) is a member of the genus Diorygma (Lecanoromycetes: Graphidaceae). Bryologist 115: 313321. doi: 10.1639/0007-2745-115.2.313

Neuwirth G, Aptroot A (2011) Recognition of four morphologically distinct species in the Graphis scripta complex in Europe. Herzogia 24: 207-230.

Papong K, Corush J, Mangold A, Lücking R, Lumbsch HT (2009) Phylogenetic position of the foliicolous genus Chroodiscus (Ostropales, Ascomycota) inferred from nuclear and mitochondrial ribosomal DNA sequences. Fungal Diversity 38: 147-153.

Parnmen S, Lücking R, Lumbsch HT (2012) Phylogenetic classification at generic level in the absence of distinct phylogenetic patterns of phenotypical variation: a case study in Graphidaceae (Ascomycota). PlosOne. [in press]

Penn O, Privman E, Landan G, Graur D, Pupko T (2010a) An alignment confidence score capturing robustness to guide-tree uncertainty. Molecular Biology and Evolution 27: 1759-67. doi: 10.1093/molbev/msq066

Penn O, Privman E, Ashkenazy H, Landan G, Graur D, Pupko T (2010b) GUIDANCE: a web server for assessing alignment confidence scores. Nucleic Acids Research 38: W23W28. doi: 10.1093/nar/gkq443

Podani J (2010) Monophyly and paraphyly: A discourse without end? Taxon 59: 1011-1015. Rivas Plata E, Lücking R (2012) High diversity of Graphidaceae (Ascomycota: Ostropales) in Amazonian Peru. Fungal Diversity. [online first] doi: 10.1007/s13225-012-0172-y 
Rivas Plata E, Lumbsch HT (2011) Parallel evolution and phenotypic disparity in lichenized fungi: a case study in the lichen-forming fungal family Graphidaceae (Ascomycota: Lecanoromycetes: Ostropales). Molecular Phylogenetics and Evolution 61: 45-63. doi: 10.1016/j.ympev.2011.04.025

Rivas Plata E, Lücking R, Lumbsch HT (2008) When family matters: an analysis of Thelotremataceae (Lichenized Ascomycota: Ostropales) as bioindicators of ecological continuity in tropical forests. Biodiversity and Conservation 17: 1319- 1351. doi: 10.1007/s10531007-9289-9

Rivas Plata E, Kalb K, Frisch A (2010a) Wirthiotrema: a new genus for the Thelotrema glaucopallens group (Ascomycota: Ostropales: thelotremoid Graphidaceae). Lichenologist 42: 187-202. doi: 10.1017/S0024282909990454

Rivas Plata E, Lücking R, Sipman HJM, Mangold A, Kalb K, Lumbsch HT (2010b) A worldwide key to the thelotremoid Graphidaceae, excluding the Ocellularia-Myriotrema-Stegobolus clade. Lichenologist 42: 139-185. doi: 10.1017/S0024282909990491

Rivas Plata E, Hernández JE, Lücking R, Staiger B, Kalb K, Cáceres MES (2011) Graphis is two genera - A remarkable case of parallel evolution in lichenized Ascomycota. Taxon 60: 99-107.

Rivas Plata E, Lumbsch HT, Lücking R (2012a) A new classification for the lichen family Graphidaceae s.lat. (Ascomycota: Lecanoromycetes: Ostropales). Fungal Diversity 52: 107-121. doi: 10.1007/s13225-011-0135-8

Rivas Plata E, Mason-Gamer R, Ashley M, Lücking R, Lumbsch HT (2012b) Molecular phylogeny and systematics of the Ocellularia-clade (Ascomycota: Ostropales: Graphidaceae). Taxon 61 (in press).

Salisbury G (1971) The Thelotremata of Angola and Mocambique. Revista de Biol.ogia (Lisbon) 7: 271-280.

Salisbury G (1972) Thelotrema Ach. sect. Thelotrema. 1. The T. lepadinum group. Lichenologist 5: 262-274. doi: 10.1017/S0024282972000271

Salisbury G (1978) Thelotrema Achariana et Feeana. Nova Hedwigia 29: 405-428.

Santesson R (1952) Foliicolous lichens I. A revision of the taxonomy of the obligately foliicolous, lichenized fungi. Symbolae Botanica Upsaliense 12(1): 1-590.

Sipman HJM, Lücking R, Aptroot A, Chaves JL, Kalb K, Umaña Tenorio L (2012) A first assessment of the Ticolichen biodiversity inventory in Costa Rica and adjacent areas: the thelotremoid Graphidaceae (Ascomycota: Ostropales). Phytotaxa 55: 1-214.

Staiger B (2002) Die Flechtenfamilie Graphidaceae. Studien in Richtung einer natürlicheren Gliederung. Bibliotheca Lichenologica 85: 1-526.

Staiger B, Kalb K (1999) Acanthothecis and other graphidioid lichens with warty periphysoids or paraphysis-tips. Mycotaxon 73: 69-134.

Staiger B, Kalb K, Grube M (2006) Phylogeny and phenotypic variation in the lichen family Graphidaceae (Ostropomycetidae, Ascomycota). Mycological Research 110: 765-772. doi: 10.1016/j.mycres.2006.05.003

Stamatakis A (2006) RAxML-VI-HPC: Maximum-Likelihood-based phylogenetic analyses with thousands of taxa and mixed models. Bioinformatics 22: 2688-90. doi; 10.1093/ bioinformatics/btl446 
Stamatakis A, Ludwig T, Meier H (2005) RAxML-III: A fast program for maximum likelihood-based inference of large phylogenetic trees. Bioinformatics 21: 456-463. doi: 10.1093/bioinformatics/bti191

Stamatakis A, Hoover P, Rougemont J (2008) A fast bootstrapping algorithm for the RAxML web-Servers. Systematic Biology 57: 758-771. doi: 10.1080/10635150802429642

Tehler A, Irestedt M, Wedin M, Ertz D (2009) Origin, evolution and taxonomy of American Roccella (Roccellaceae, Ascomycetes). Systematics and Biodiversity 7: 307-317. doi: $10.1017 /$ S1477200009990065

Tehler A, Irestedt M, Wedin M, Ertz D (2010) The Old World Roccella species outside Europe and Macaronesia: taxonomy, evolution and phylogeny. Systematics and Biodiversity 8: 223-246. doi: 10.1080/14772001003789554

Tibell L (1994) Distribution patterns and dispersal strategies of Caliciales. Journal of the Linnean Society, Botany 116: 159-202.

Vezda A, Poelt J (1987) Flechtensystematische Studien. XII. Die Familie Gomphillaceae und ihre Gliederung. Folia Geobotanica et Phytotaxonomica (Praha) 22:179-198.

Vilgalys R, Hester M (1990) Rapid genetic identification and mapping of enzymatically amplified ribosomal DNA from several Cryptococcus species. Journal of Bacteriology 172: 4238-4246.

Wirth M, Hale ME Jr (1963) The lichen family Graphidaceae in Mexico. Contributions from the United States National Herbarium 36(3): 63-119.

Wirth M, Hale ME Jr (1978) Morden-Smithsonian Expedition to Dominica: the lichens (Graphidaceae). Smithsonian Contributions to Botany 40: 1-64. doi: 10.5479/ si.0081024X.40

Zahlbruckner A (1905) Thelotremaceae und Diploschistaceae. In: Engler-Prantl, Natürliche Pflanzenfamilien, 1. Teil, Abt. 1: Lichenes (Flechten). Spezieller Teil: 118-122. Leipzig.

Zoller S, Scheidegger C, Sperisen C (1999) PCR primers for the amplification of mitochondrial small subunit ribosomal DNA of lichen-forming ascomycetes. Lichenologist 31: 511-516. 


\section{Appendix I}

GenBank numbers and voucher information for specimens and sequences used in this study, sorted alphabetically by taxon, country, and collector. (doi: 10.3897/mycokeys.6.3482.app1) Microsoft Word Document (doc).

Copyright notice: This dataset is made available under the Open Database License (http://opendatacommons.org/licenses/odbl/1.0/). The Open Database License (ODbL) is a license agreement intended to allow users to freely share, modify, and use this Dataset while maintaining this same freedom for others, provided that the original source and author(s) are credited.

Citation: Rivas Plata E, Parnmen S, Staiger B, Mangold A, Frisch A, Weerakoon G, Hernández M JE, Cáceres MES, Kalb K, Sipman HJM, Common RS, Nelsen MP, Lücking R, Lumbsch HT (2012) A molecular phylogeny of Graphidaceae (Ascomycota, Lecanoromycetes, Ostropales) including 428 species. MycoKeys 6: 55-94. doi: 10.3897/mycokeys.6.3482. app1

\section{Appendix 2}

Full, best-scoring maximum-likelihood tree of the combined 3-gene dataset of all OTUs, showing detailed bootstrap support values. Genus-level clades are highlighted in blue and orange and unresolved or orphaned species-level clades are in black. (doi: 10.3897/ mycokeys.6.3482.app2) File format: Adobe Portable Document Format (pdf).

Copyright notice: This dataset is made available under the Open Database License (http://opendatacommons.org/licenses/odbl/1.0/). The Open Database License (ODbL) is a license agreement intended to allow users to freely share, modify, and use this Dataset while maintaining this same freedom for others, provided that the original source and author(s) are credited.

Citation: Rivas Plata E, Parnmen S, Staiger B, Mangold A, Frisch A, Weerakoon G, Hernández M JE, Cáceres MES, Kalb K, Sipman HJM, Common RS, Nelsen MP, Lücking R, Lumbsch HT (2012) A molecular phylogeny of Graphidaceae (Ascomycota, Lecanoromycetes, Ostropales) including 428 species. MycoKeys 6: 55-94. doi: 10.3897/mycokeys.6.3482. app2 